Eastern Illinois University

The Keep

Faculty Research and Creative Activity

Chemistry

March 2012

\title{
Room temperature syntheses of entirely diverse substituted $\beta$-fluorofurans
}

Li Yan

Oakland University

Kraig A. Wheeler

Eastern Illinois University, kawheeler@eiu.edu

Roman Dembinski

Oakland University

Follow this and additional works at: http://thekeep.eiu.edu/chemistry_fac

Part of the Organic Chemistry Commons

\section{Recommended Citation}

Yan, Li; Wheeler, Kraig A.; and Dembinski, Roman, "Room temperature syntheses of entirely diverse substituted $\beta$-fluorofurans" (2012). Faculty Research and Creative Activity. 9.

http://thekeep.eiu.edu/chemistry_fac/9

This Article is brought to you for free and open access by the Chemistry at The Keep. It has been accepted for inclusion in Faculty Research and Creative Activity by an authorized administrator of The Keep. For more information, please contact tabruns@eiu.edu. 


\section{Organic \& Biomolecular Chemistry}

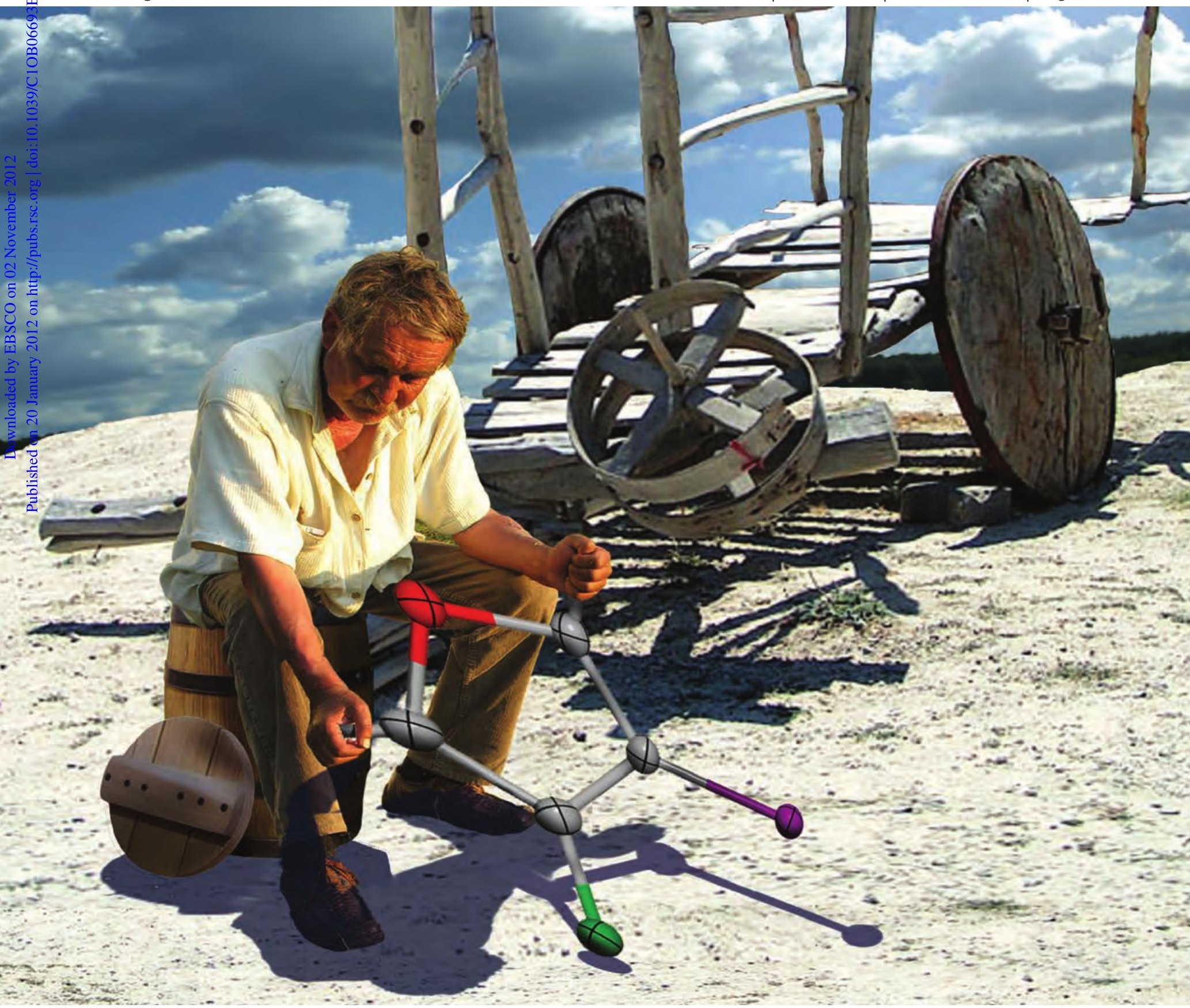




\title{
Room temperature syntheses of entirely diverse substituted $\beta$-fluorofurans $\dagger$
}

\author{
Yan Li, ${ }^{a}$ Kraig A. Wheeler ${ }^{b}$ and Roman Dembinski*a \\ Received 5th October 2011, Accepted 17th November 2011 \\ DOI: $10.1039 / \mathrm{c} 10 b 06693 \mathrm{e}$
}

Synthesis of highly substituted 3 -fluorofurans is reported. The sequence began with preparation of tertbutyldimethylsilyl alk-1-en-3-yn-1-yl ethers from 1,4-disubstituted alk-3-yn-1-ones. Subsequent fluorination of alkenynyl silyl ethers with Selectfluor gave 2-fluoroalk-3-yn-1-ones in almost quantitative yield. Subsequent 5-endo-dig cyclizations using chlorotriphenylphosphine gold(I)/silver trifluoromethanesulfonate (5/5 mol\%), $N$-bromo- or $N$-iodosuccinimide and gold(I) chloride/zinc bromide $(5 / 20 \mathrm{~mol} \%)$, all at room temperature, provided a facile method for the generation of substituted 3-fluoro-, 3-bromo-4-fluoro-, and 3-fluoro-4-iodofurans in good yields. Also, 2,2-difluoroalk-3-yn-1-ones were prepared by fluorination of alk-3-yn-1-ones under organocatalytic conditions. The structures of (Z)-tertbutyldimethylsilyl but-1-en-3-yn-1-yl ether, 3-bromo-4-fluorofuran, and 3-fluoro-4-(phenylethynyl)furan were confirmed by X-ray crystallography.

\section{Introduction}

Active pharmaceutical ingredients incorporating the fluorine atom have found wide applications in the field of medicinal chemistry. ${ }^{1,2}$ Currently, fluorine-containing compounds are leading in the list of best-selling drugs. ${ }^{3}$ In fact, fluorofuran or perfluoroalkylfuran fragments have already been embedded within structures possessing interesting pharmacological properties. ${ }^{4,5}$ Since the furan ring constitutes a submotif of medicinal interest, ${ }^{6}$ corresponding fluorinated molecules are highly sought after building blocks. Thus, upon considering the pharmaceutical potential, as well as the limitations of available synthetic methods for 3-fluorofurans, we decided to pursue the development of their synthesis.

Halofurans are important derivatives, extensively utilized for the preparation of acyclic, carbocylic, and heterocyclic compounds. In addition, halofurans provide an opportunity for further functionalization. In particular, iodo-, bromo-, and also recently chlorofurans have been useful substrates for a variety of bond-forming reactions. ${ }^{7-11}$ In general, approaches to the synthesis of $\beta$-halofurans can be divided into substitution reactions on the furan core and the construction of a furan ring starting from acyclic precursors. ${ }^{12,13}$ The later centers on cycloisomerization or cyclocondensation reactions and includes halogenation/ cyclizations, and cyclizations of precursors that contain already

${ }^{a}$ Department of Chemistry, Oakland University, 2200 N. Squirrel Rd, Rochester, MI 48309-4477, USA. E-mail: dembinsk@oakland.edu ${ }^{b}$ Eastern Illinois University, 600 Lincoln Avenue, Charleston, IL 619203099, USA

$\dagger$ Electronic supplementary information (ESI) available: ${ }^{1} \mathrm{H},{ }^{13} \mathrm{C}$, and ${ }^{19} \mathrm{~F}$ NMR spectra for difluorobutynones 4, silyl ethers $\mathbf{6}$, and fluorofurans 10-13. CCDC reference numbers 826570,826571 and 827011 . For ESI and crystallographic data in CIF or other electronic format see DOI: $10.1039 / \mathrm{c} 1 \mathrm{ob} 06693 \mathrm{e}$ introduced halogens. Electrophilic cyclization reactions are particularly attractive since they provide versatile access to different halofurans by treatment of the same starting material with different halogens. ${ }^{14,15}$ Usually the electrophile acts as both the cyclization initiator and a halogen donor, thus fostering material economy. However, fluorine, due to its limited electrophilic character, is not effective in electrophilic cyclizations. ${ }^{16}$ So far, preparative access to 3 -fluorofurans includes only a few specific methods; the syntheses usually encompass aggressive conditions or poor yields. ${ }^{12}$

Only scarce reports provide a preparative route to $\beta, \beta^{\prime}$ fluorohalofurans, which offer an opportunity for further functionalization of fluorofurans. The iodocyclization of gem-difluorohomopropargyl alcohols (2,2-difluoroalk-3-yn-1-ols) can be induced by iodine monochloride in the presence of a base and microwave irradiation. ${ }^{7}$ Subsequent silica gel aromatization of 3,3-difluoro-4iodo-2,3-dihydrofurans leads to the 3-fluoro-4-iodofurans. Only one example of 3-bromo-4-fluorofuran, prepared by a sequential lithiation/bromination reaction of 3-fluoro-2,5-diphenylfuran, has been reported with undisclosed preparative yield. ${ }^{17}$

In order to access a family of $\beta$-fluorofurans (1), we elected to introduce fluorine into an acyclic skeleton and to use 2-fluoroalk-3-yn-1-ones (2) as a versatile cyclization starting material (Scheme 1). ${ }^{18,19}$ Fluoroalkynone 2 contains one less fluorine

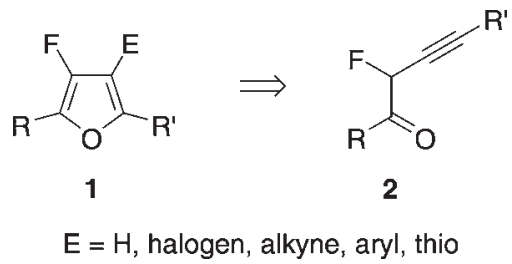

Scheme 1 Retrosynthetic approach to $\beta$-fluorofurans. 
atom in comparison to the gem-difluorohomopropargyl alcohol, hence it should prove to be more versatile and reactive towards cyclization reactions. This substrate would generate a convergent synthetic opportunity to also obtain $\beta, \beta^{\prime}$-fluorohalofurans.

Thus far, the preparations of 2-fluoroalk-3-yn-1-ones 2 have been reported via the oxidation of 2-fluoroalk-3-yn-1-ols, which are accessed by a low-yielding ring opening of an oxirane precursor by a fluoride anion, ${ }^{20}$ or via a zinc- or indium(III) chloride-catalyzed reaction of fluoropropargyl halides with carbonyl compounds. $^{21,22}$ Therefore, we sought to secure more convenient access to fluoroalkynones $\mathbf{2}$ as key starting materials, establish their cyclization reactions at mild conditions despite the thwarting influence of fluorine atom on their reactivity, and finally, functionalize the iododerivatives to trisubstituted 3-fluorofurans. The current results extend our exploration of cycloisomerization and electrophilic halocyclization reactions. ${ }^{10,23-26}$ Here we report our attempts towards the syntheses of a family of substituted $\beta$-fluorofurans 1 from alk-3-yn-1-ones 3.

\section{Results and discussion}

We sought to develop a more effective fluorofuran synthesis in terms of halogen atom economy. To introduce a fluorine atom at the relatively late stage of the synthesis we envisioned direct fluorination of alk-3-yn-1-ones $\mathbf{3}$ in a joint $\alpha$-position to the alkyne and ketone. ${ }^{27}$ Monofluorination procedures for regular ketones at their $\alpha$-carbon are known. ${ }^{28-30}$ However, a reaction of alkynone 3a with NFSI (1 equiv), in the presence of the inorganic base (potassium carbonate), leads to isolation of the difluoro derivative $\mathbf{4 a} .^{31}$ Since monofluorination of regular ketones can also be accomplished under organocatalytic conditions, $^{32}$ an analogous approach was investigated. Unfortunately, the reaction of alkynone 3 a with Selectfluor $^{33}$ (1.1 equiv), in the presence of L-proline $(10 \mathrm{~mol} \%)$ and molecular sieves, led again to a mixture of monofluoro and difluoro derivatives $2 \mathbf{a}$ and $4 \mathbf{a}$ (4.5:1 ratio) that were difficult to separate. Since the $\alpha$-proton of $\mathbf{2} \mathbf{a}$ is more acidic than the one in substrate $\mathbf{3 a}$, the product, in the presence of a base, equilibrates to a competitive enolate.

Considering the popular use of difluoropropargyl moieties in synthetic $^{34,35}$ and biological chemistry ${ }^{36}$ we took the opportunity to integrate mild organocatalytic conditions into the preparation of the difluoro derivatives $\mathbf{4}$. So far, fluoroalkynones $\mathbf{4}$ have been prepared starting from chlorofluorocarbons via gem-difluorohomopropargyl alcohols. ${ }^{37}$ When the alkynones 3a,e were reacted with Selectfluor (2.3 equiv) in the presence of L-proline $(20 \mathrm{~mol}$ $\%$ ) and $5 \AA$ molecular sieves (acetonitrile, room temperature), difluoroalkynones 4a,e were isolated with $63 \%$ and $67 \%$ yield (Scheme 2). The convenient access to alkynones $\mathbf{3}$ include, among others, oxidation of alkynols $\mathbf{5} .^{38,39}$

Furthermore, alternative access to fluoroketones $\mathbf{2}$, in the absence of a base was pursued. Electrophilic fluorodesilylation of silyl enol ethers has literature precedence. ${ }^{16,40}$ However, we were unable to find a general synthesis of alk-1-en-3-yn-1-yl silyl ethers 6. So far, synthetic methods for silyl ethers (silyloxy enynes) of type 6 have only been described for individual compounds. Literature reports include the reaction of an alkynyl oxirane with $\mathrm{BuLi}$ in the presence of $\mathrm{TMSCl}^{41}$ rearrangement of

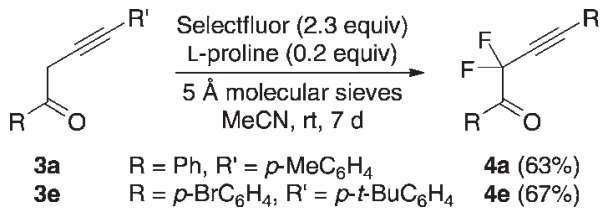

Scheme 2 Fluorination of butynones 3a,e.

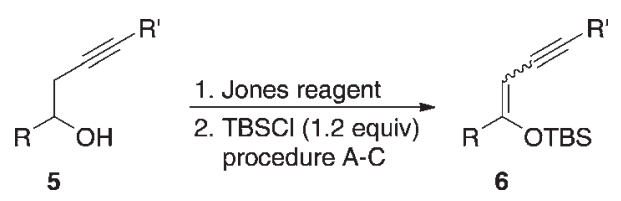

Scheme 3 Synthesis of silyl ethers 6. Procedures: A) LDA (1.1 equiv), THF, $-78{ }^{\circ} \mathrm{C}$ to $\mathrm{rt}, 12 \mathrm{~h}$. B) LDA (1.1 equiv), TMEDA (1.2 equiv), THF, $-78{ }^{\circ} \mathrm{C}$ to rt, 12 h. C) DBU (1.1 equiv), NaI (0.2 equiv), acetonitrile, rt, $4 \mathrm{~h}$.

an $\alpha$-alkoxy carbene derived from aldehyde and $\mathrm{N}$-amino-2,3diphenylaziridine derivative, ${ }^{42}$ or ring opening of furans. ${ }^{43}$ The pathway starting from alkynones 3 via enolization has not yet been reported.

The conversion of alkynone $3 \mathbf{a}^{24 a}$ to the corresponding $t$-butyldimethylsilyl enol ether $\mathbf{6 a}$ and its trimethylsilyl lower homolog was accomplished using a procedure similar to the literature protocol for regular silyl ether. ${ }^{44}$ Since 6 a was sufficiently stable for isolation by column chromatography, the remaining silyl enol ethers $\mathbf{6 b}-\mathbf{h}$ were then prepared as the $t$-butyldimethylsilyl derivatives.

Although some of the solid alkynones $\mathbf{3}$ can be isolated via crystallization and stored for months in a refrigerator, frequent instability of liquids or solutions was encountered. The lack of an effective and timely purification procedure, especially for compounds $\mathbf{3 g}$ and $\mathbf{3 h}$, prompted us to begin the synthesis from alkynols $\mathbf{5}$. Since the oxidation of $\mathbf{5}$ with a Jones reagent is efficient, ${ }^{38}$ ketones $\mathbf{3}$ were used as a crude material in a two step process (Scheme 3 ).

The enolate was initially formed via deprotonation of alkynone 3a with LDA in THF at $-78^{\circ} \mathrm{C}$ (procedure A, Table 1). Additional optimization of the preparative procedure was sought. TMEDA, a bidentate ligand coordinating lithium was added (2 equiv, procedure B), affording the enolate with comparable or slightly higher yields. The silylation did not proceed with a higher reaction rate. The substrate with the cyclopropyl alkynyl group gave a low yield of silyl ether $\mathbf{6 b}$ with procedure A $(11 \%$, Table 1, entry 2). Applying conditions B resulted in a complex reaction mixture without detectable amounts of silyl ether $\mathbf{6 b}$, presumably due to the sensitivity of the cyclopropyl group towards the reaction environment. Therefore thermodynamic conditions (procedure C) for the cyclopropyl-containing substrate were tried. The combination of the cyclopropyl ketone, DBU (1.1 equiv), TBSCl (1.2 equiv), and $\mathrm{NaI}$ ( 0.2 equiv) in anhydrous acetonitrile at ambient temperature gave $\mathbf{6 b}$ in $60 \%$ yield (two step synthesis starting from $\mathbf{5 b}, 5 \mathrm{mmol}$ scale). The substrate with the phenoxymethyl group, derived from glycidol, was converted to its ether $\mathbf{6 h}$ using conditions $\mathrm{C}$ as well $(55 \%$ yield, Table 1). 
Table 1 Synthesis of silyl ethers 6

\begin{tabular}{|c|c|c|c|c|c|}
\hline Alkynol 5 & $\mathrm{R}$ & $\mathrm{R}^{\prime}$ & Procedure & $\begin{array}{l}\text { Yield } \\
6[\%]\end{array}$ & $\begin{array}{l}E / Z \\
\text { ratio }^{46}\end{array}$ \\
\hline \multirow[t]{2}{*}{$\mathbf{a}$} & \multirow[t]{2}{*}{$\mathrm{Ph}$} & \multirow{2}{*}{$p-\mathrm{MeC}_{6} \mathrm{H}_{4}$} & A & 52 & $16: 84$ \\
\hline & & & B & & $13: 87$ \\
\hline \multirow[t]{2}{*}{ b } & \multirow[t]{2}{*}{$\mathrm{Ph}$} & \multirow[t]{2}{*}{$c-\mathrm{C}_{3} \mathrm{H}_{5}$} & $\begin{array}{l}\text { A } \\
\text { B }\end{array}$ & $\begin{array}{l}11 \\
\text { nd }^{a}\end{array}$ & $\begin{array}{l}\text { nd } \\
\text { nd }\end{array}$ \\
\hline & & & $\mathrm{C}$ & 60 & $8: 92$ \\
\hline \multirow[t]{3}{*}{ c } & \multirow[t]{3}{*}{$p-\mathrm{FC}_{6} \mathrm{H}_{4}$} & \multirow{3}{*}{$p-\mathrm{MeC}_{6} \mathrm{H}_{4}$} & A & 28 & $26: 74$ \\
\hline & & & B & 32 & $17: 83$ \\
\hline & & & $\mathrm{C}$ & 52 & $2: 98$ \\
\hline \multirow[t]{2}{*}{ d } & \multirow[t]{2}{*}{$p-\mathrm{BrC}_{6} \mathrm{H}_{4}$} & \multirow[t]{2}{*}{$p-\mathrm{MeC}_{6} \mathrm{H}_{4}$} & A & 65 & nd \\
\hline & & & B & 62 & $2: 98$ \\
\hline \multirow[t]{2}{*}{ e } & \multirow[t]{2}{*}{$p-\mathrm{BrC}_{6} \mathrm{H}_{4}$} & \multirow[t]{2}{*}{$p-t-\mathrm{BuC}_{6} \mathrm{H}_{4}$} & A & 59 & nd \\
\hline & & & B & 68 & $6: 94$ \\
\hline f & $p-\mathrm{CF}_{3} \mathrm{C}_{6} \mathrm{H}_{4}$ & $p-\mathrm{MeC}_{6} \mathrm{H}_{4}$ & B & 61 & $3: 97$ \\
\hline g & Et & $\mathrm{Ph}$ & A & 68 & $89: 11^{b}$ \\
\hline h & $\mathrm{PhOCH}_{2}$ & $p-\mathrm{MeC}_{6} \mathrm{H}_{4}$ & $\mathrm{C}$ & 55 & $22: 78$ \\
\hline
\end{tabular}

nd $=$ not determined. ${ }^{a}$ Complex reaction mixture. ${ }^{b}$ Tentative $E / Z$ assignment based upon ${ }^{1} \mathrm{H}$ NMR.

The substrate $\mathbf{5 g}$ with an ethyl substituent leads to a ketone with two carbons available for enolization. Under kinetic conditions (procedure A), formation of the conjugated ether $\mathbf{6 g}$ was observed. The ethyl substituted ether $\mathbf{6 g}$ was rather unstable; after a slower silica gel column chromatography a fraction was collected that was rich in corresponding allenyl ketone. ${ }^{45}$ Apparently desilylation of silyl ether and isomerization had occurred. Fast filtration through a plug of deactivated silica gel brought access to $\mathbf{6 g}$ that was still accompanied with a small amount of allenyl ketone.

The silyl ethers $\mathbf{6} \mathbf{a}-\mathbf{h}$ were obtained in $52-68 \%$ overall yield (Table 1) after purification by column chromatography. The prolonged contact of silyl ethers $\mathbf{6}$ with silica gel was detrimental to the yield; the optimum preparative scale was established as $6 \mathrm{mmol}$ ( $>1 \mathrm{~g}$ ). On a smaller scale, such as $0.5 \mathrm{mmol}$, yields were usually higher since the chromatography procedure can be completed more rapidly.

After isolation, the predominance of one stereoisomer was observed. The structural assignments of regular silyl enol ethers are frequently based upon the chemical shift of vinyl protons in the ${ }^{1} \mathrm{H}$ NMR spectrum ${ }^{47,48}$ or, trustworthier, of allylic carbons in the ${ }^{13} \mathrm{C}$ NMR spectrum. ${ }^{49,50}$ However, such an assignment may not necessarily extrapolate into the $s p$ carbons of a triple bond or ipso carbons of an aryl ring, which, due to low relaxation,

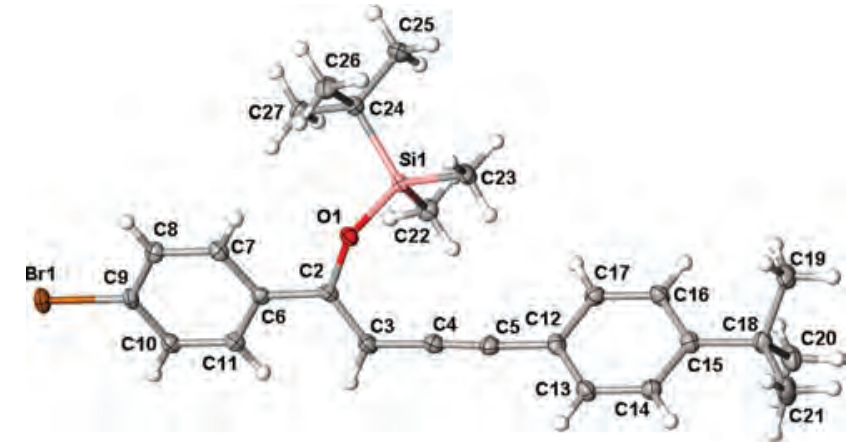

Fig. 1 An ORTEP view of 6 e illustrating the atom labeling scheme and thermal ellipsoids $(50 \%$ probability level). Selected interatomic distances $(\AA)$ : Si1-O1 1.6742(14), O1-C2 1.361(2), C2-C3 1.346(3), C2C6 1.477(3), C3-C4 1.421(3), C4-C5 1.209(3), C5-C12 1.435(3). Key angles $\left({ }^{\circ}\right)$ : Si1-O1-C2 130.81(13), O1-C2-C3 122.16(19), C3-C2-C6 123.12(18), O1-C2-C6 114.60(18), C2-C3-C4 124.92(19), C3-C4-C5 178.2(2), C4-C5-C12 176.3(2).

usually require longer acquisition time. Accordingly, we were not able to observe the relevant $\mathrm{C} \equiv \mathrm{C}$ signals for the low abundant isomer. Table 2 summarizes the chemical shift trends for the signals that differentiated both isomers.

Due to lack of stereochemical $E / Z$ assignments for silyloxy enynes $^{49}$ an unequivocal confirmation was sought. Fortunately, slow evaporation of a hexane/ethyl acetate solution of compound 6e gave a single crystal suitable for X-ray analysis. Inspection of Fig. 1 reveals the molecular structure of the $Z$-silyl enol ether $\mathbf{6 e}$. This result is in agreement with the dominant $Z$ stereochemistry for silyl ethers derived from phenyl-substituted ketones. ${ }^{47}$

The fluorination reaction simplified the stereochemical outcome. Since $E$ and $Z$ stereoisomers presumably produce the same racemic mixture of 2-fluoroalkynone 2, the mixture of both stereoisomers was subjected to the reaction. The reaction of $\mathbf{6 a}$ with Selectfluor at room temperature gave a monofluoroketones $\mathbf{2 a}$ in almost quantitative yield (Scheme 4). ${ }^{23}$ Fluoroketone $\mathbf{2 b}$ was also characterized by NMR.

Non-fluorinated alkynones $\mathbf{3}$ can be converted to furans using zinc, silver, palladium, and other transition metals-containing catalysts. $^{24 a, 51}$ Unfortunately cycloisomerization of $\mathbf{2 a}$ with zinc chloride etherate or silver nitrate was inhibited by the electron withdrawing effect of fluorine (Table 3 , entry 1 and 2). When fluoroketone 2 was treated with the $\left(\mathrm{PhCN}_{2} \mathrm{PdCl}_{2}(10 \mathrm{~mol} \%),{ }^{19}\right.$ fluorofuran $7 \mathbf{a}$ was isolated in $60 \%$ yield.

Table 2 NMR resonances for silyl ethers isomers $6^{a}$

\begin{tabular}{lllllll}
\hline Silyl ether 6 & Ratio & $\mathrm{C}=\mathrm{CH}$ major/min & $\mathrm{CH}_{3} \mathrm{Si}$ major/min & $\left(\mathrm{CH}_{3}\right)_{3} \mathrm{CSi}$ major/min & $\mathrm{C}=\mathrm{CH}$ major/min & $\mathrm{CH} \mathrm{H}_{3} \mathrm{Si}$ major/minor \\
\hline $\mathbf{a}$ & $87: 13$ & $5.59 / 5.38$ & $0.17 / 0.21$ & $1.03 / 1.00$ & $91.0 / 90.4$ & $-3.6 /-4.3$ \\
$\mathbf{b}$ & $92: 8$ & $5.31 / 5.14$ & $0.13 / 0.16$ & $1.01 / 0.97$ & $91.1 / 90.8$ & $-3.6 /-4.3$ \\
$\mathbf{c}$ & $98: 2$ & $5.52 / 5.31$ & $0.17 / 0.21$ & $1.02 / 0.99$ & $90.8 / \mathrm{nd}$ & $-3.5 / \mathrm{nd}$ \\
$\mathbf{d}$ & $98: 2$ & $5.58 / 5.39$ & $0.18 / 0.21$ & $1.02 / 0.99$ & $91.5 / 90.4$ & $-3.5 / \mathrm{nd}$ \\
$\mathbf{e}$ & $94: 6$ & $5.59 / 5.40$ & $0.19 / 0.21$ & $1.03 / 0.99$ & $91.6 / \mathrm{nd}$ & $-3.5 /-4.3$ \\
$\mathbf{f}$ & $97: 3$ & $5.68 / 5.48$ & $0.19 / 0.23$ & $1.03 / 1.00$ & $92.9 / \mathrm{nd}$ & $-3.5 / \mathrm{nd}$ \\
$\mathbf{g}$ & $89: 11$ & $4.89 / 4.93$ & $0.22 / \mathrm{na}$ & $0.96 / \mathrm{na}$ & $91.7 / 91.5$ & $-4.3 /-3.6$ \\
$\mathbf{h}$ & $78: 22$ & $5.32 / 5.23$ & $0.32 / 0.17$ & $1.01 / 0.93$ & $90.9 / \mathrm{nd}$ & $-3.7 /-4.4$
\end{tabular}

nd $=$ not detected. na $=$ not assigned. ${ }^{a}{ }^{1} \mathrm{H} /{ }^{13} \mathrm{C} 400 / 100 \mathrm{MHz}, \mathrm{CDCl}_{3}, 22{ }^{\circ} \mathrm{C}, \delta$, ppm. 


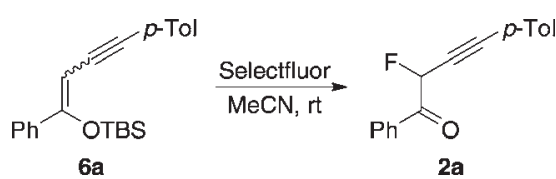

Scheme 4 Synthesis of 2-fluorobutynone 2a.

Cationic gold compounds show unique activities toward alkynes, promoting the nucleophilic addition of a variety of functional groups inter- and intramolecularly. Heterocycle formation via vinyl-gold type intermediates that can be isolated has already been established. ${ }^{52}$ Gold catalysts such as $\mathrm{AuCl}_{3}, \mathrm{AuCl}$, and $\mathrm{PPh}_{3} \mathrm{AuCl}$ have proved effective in the cyclization reactions. ${ }^{53}$ Although gold(I) and (III) are both carbophilic, their complexes could differ in selectivity for the same reactant. Au(III) exhibits a thermodynamic preference for heteroatom coordination over carbon-carbon multiple bonds (and has a relatively high oxidative potential), while $\mathrm{Au}(\mathrm{I})$ increases the relative strength of coordination to the carbon-carbon multiple bonds. ${ }^{54}$ The use of $\mathrm{AuCl}_{3}(5 \mathrm{~mol} \%)$ led to the formation of multiple products (Table 3, entry 4). When $\mathrm{AuCl}$ ( $5 \mathrm{~mol} \%$ ) was combined with 2a in anhydrous DCM at ambient temperature, the reaction showed no conversion to the fluorofuran in $2 \mathrm{~h}$, although trace amounts of other products were observed in the ${ }^{1} \mathrm{H}$ NMR and ${ }^{19}$ F NMR (Table 3, entry 5). An easy-to-handle (air-stable) and commercially available triphenylphosphine gold(I) chloride was selected for investigation. The coordination with triphenylphosphine decreases the Lewis acidity of auric salts, and the triphenylphophine gold triflate $\left(\mathrm{Ph}_{3}\right.$ PAuOTf) derivative is a more dissociated complex with increased electrophilicity at the gold center. The air stable $\mathrm{Ph}_{3}$ PAuOTf was generated in situ from triphenylphosphine gold(I) chloride and silver trifluoromethanesulfonate (both $5 \mathrm{~mol} \%$ ), in dichloromethane, at room temperature, and facilitated almost quantitative conversion of $\mathbf{2 a}$ into furan $\mathbf{7 a}$ (Table 3, entry 6).

Lowering the $\mathrm{Ph}_{3} \mathrm{PAuOTf}$ catalyst load to $1 \mathrm{~mol} \%$ was ineffective due to slow conversion (Table 3, entries 7-9). In further efforts to reduce the amount of gold/silver catalytic system increase of enolization was sought by an addition of a co-catalyst that would be compatible with the gold triflate acting species. ${ }^{55}$ In order to maintain the presence of the counterion, zinc triflate seemed to be a logical choice. When $\mathrm{Ph}_{3}$ PAuOTf ( $\left.1 \mathrm{~mol} \%\right)$ was combined with $\mathrm{Zn}(\mathrm{OTf})_{2}(5 \mathrm{~mol} \%$, DCM, rt) and fluorobutynone $\mathbf{2 a}$, the quantitative formation of fluorofuran $\mathbf{7 a}$ was confirmed by ${ }^{19} \mathrm{~F}$ NMR. The reaction required $2 \mathrm{~h}$ for completion (Table 3, entry 10). The same reaction time and concentration with $1 \quad \mathrm{~mol}_{\%} \quad \mathrm{Ph}_{3}$ PAuOTf gave only $8 \%$ of the fluorofuran $7 \mathbf{a}$ (Table 3, entry 7). The control experiment using only $\mathrm{Zn}(\mathrm{OTf})_{2}(20 \mathrm{~mol} \%, 12 \mathrm{~h})$ showed no conversion of $\mathbf{2 a}$ (Table 3, entry 11). To clarify the role of the counterion, the reaction was carried out with $5 \mathrm{~mol} \% \mathrm{Ph}_{3} \mathrm{PAuBF}_{4}$, and full conversion was observed (Table 3, entry 12). Thus, it can be concluded that the catalytic system does not depend significantly on the counterion. ${ }^{56}$ It is in line with the report that the non-triflate system $\mathrm{Ph}_{3} \mathrm{PAuCl} / \mathrm{Zn}\left(\mathrm{ClO}_{4}\right)_{2}$ is as well an effective catalyst. ${ }^{55}$

Preparation of alk-3-yn-1-ones (propargyl ketones), the necessary starting materials, was carried out as described earlier. $^{24,57}$ Although we focused on aryl substituents, we also examined compounds containing one alkyl, and one cycloalkyl group. The explored substituents of silyl enol ethers $\mathbf{6}$ include aryl, ethyl, cyclopropyl, and phenoxymethyl; detailed structures are provided in Table 1.

Due to the gradual decomposition of the monofluoroketones during storage in solution and our inability to establish an effective purification procedure (especially for $\mathbf{2 g}$ and $\mathbf{2 h}$ ), a sequence of consecutive fluorination and cyclization reactions, starting from silyl enol ethers $\mathbf{6}$ and proceeding in the same flask, without isolation of 2-fluoroalkynones 2 (Scheme 5) was used for preparative purposes (Table 4). Unfortunately attempted fluorination of silyl ether $\mathbf{6 h}$ gave a complex reaction mixture at both $\mathrm{rt}$ and $0{ }^{\circ} \mathrm{C} .{ }^{58}$ Hence no cyclization reactions with the use of this compound were pursued.

The electron withdrawing effect of fluorine significantly inhibits not only the cycloisomerization process of fluorinated alkynones, but the halocyclization as well. To fine-tune the catalytic system, optimization was carried out for the bromocyclization reaction, using fluoroketone $\mathbf{2} \mathbf{a}$ as a model compound. The better stability of formed bromofuran towards gold catalyst along with the milder halogenation reagent (NBS) provided an advantage over the initial optimization results acquired for the iodocyclization reaction. ${ }^{25}$ The bromination reactions were cleaner; essentially since only the product and unreacted substrate were observed.

Table 3 Catalyst optimization: cycloisomerization of fluorobutynone 2a

\begin{tabular}{|c|c|c|c|c|c|}
\hline Entry & Catalyst & Loading $[\mathrm{mol} \%]$ & Solvent & Conditions & Yield $[\%]$ \\
\hline 1 & $\mathrm{ZnCl}_{2}$ & 100 & DCM & reflux, $3 \mathrm{~h}$ & no reaction \\
\hline 2 & $\mathrm{AgNO}_{3}$ & 10 & acetone & $\mathrm{rt}, 4 \mathrm{~h}$ & no reaction \\
\hline 3 & $(\mathrm{PhCN})_{2} \mathrm{PdCl}_{2}$ & 10 & $\mathrm{DCM}$ & $\mathrm{rt}, 1 \mathrm{~h}$ & $60^{a}$ \\
\hline 4 & $\mathrm{AuCl}_{3}$ & 5 & acetonitrile & $\mathrm{rt}, 30 \mathrm{~min}$ & $\mathrm{nd}^{c}$ \\
\hline 5 & $\mathrm{AuCl}$ & 5 & DCM & $\mathrm{rt}, 2 \mathrm{~h}$ & no reaction \\
\hline 6 & $\mathrm{Ph}_{3} \mathrm{PAuCl} / \mathrm{AgOTf}$ & 5 & DCM & $\mathrm{rt}, 10 \mathrm{~min}$ & $95^{a}$ \\
\hline 7 & $\mathrm{Ph}_{3} \mathrm{PAuCl} / \mathrm{AgOTf}$ & 1 & DCM & $\mathrm{rt}, 10 \mathrm{~min}$ & trace \\
\hline 8 & $\mathrm{Ph}_{3} \mathrm{PAuCl} / \mathrm{AgOTf}$ & 1 & DCM & $\mathrm{rt}, 2 \mathrm{~h}$ & $8^{b}$ \\
\hline 9 & $\mathrm{Ph}_{3} \mathrm{PAuCl} / \mathrm{AgOTf}$ & 1 & DCM & $\mathrm{rt}, 12 \mathrm{~h}$ & $42^{a, c}$ \\
\hline 10 & $\mathrm{Ph}_{3} \mathrm{PAuCl} / \mathrm{AgOTf}+\mathrm{Zn}(\mathrm{OTf})_{2}$ & $1+5$ & DCM & $\mathrm{rt}, 2 \mathrm{~h}$ & $>98^{b}$ \\
\hline 11 & $\mathrm{Zn}(\mathrm{OTf})_{2}$ & 20 & $\mathrm{DCM}$ & $\mathrm{rt}, 12 \mathrm{~h}$ & no reaction ${ }^{b}$ \\
\hline 12 & $\mathrm{Ph}_{3} \mathrm{PAuCl} / \mathrm{AgBF}_{4}$ & 5 & $\mathrm{DCM}$ & $\mathrm{rt}, 10 \mathrm{~min}$ & $>98^{b}$ \\
\hline
\end{tabular}




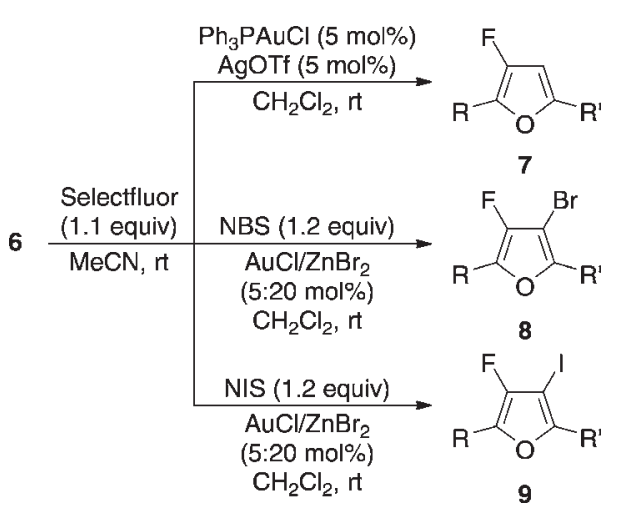

Scheme 5 Synthesis of fluorofurans 7, 8, and 9 via sequence of fluorination/cyclization.

Bromofurans, as compared to iodo derivatives, are less reactive. Therefore, it was projected that side products would originate from different reaction pathways of the substrate than from the follow-up reaction involving the product. As anticipated, side products were less abundant for bromocyclization process. Efforts for catalytic system optimization are summarized in Table 5. The reaction with only NBS (1.2 equiv) gave meager conversion after $10 \mathrm{~min}$ (Table 5, entry 1 ). The addition of gold(I) chloride (5 mol\%) accelerated the reaction in a minor way (Table 5, entries 2 and 3). Bromocyclization in the presence of $\mathrm{ZnBr}_{2}$ (20 mol\%) was more effective, with a $43 \%$ conversion after $10 \mathrm{~min}$ and almost quantitative conversion after prolonged time, or with the use of larger amount of the catalyst (Table 5, entries 4-7). We were delighted to notice that a combination of gold(I) chloride (5 mol\%) and $\mathrm{ZnBr}_{2}(20 \mathrm{~mol} \%)$ gave almost quantitative conversion within 10 min (entry 8).

Separation of halofurans from regular furans that could potentially form during the reaction as side or competing products are difficult to achieve by silica gel column chromatography due to overlapping $R_{\mathrm{f}}$ values. To our delight, we did not observe by ${ }^{1} \mathrm{H}$ NMR formation of the non-halogenated fluorofurans 7 in the halocyclizations post reaction mixtures, which spared a potentially tedious separation of $\mathrm{H}$-furans from halofurans and facilitated reasonable yields (Table 4).

The molecular structure of a dihalofuran was confirmed by X-ray crystallography. Crystallization of compound 8a from ether gave single crystals suitable for $\mathrm{X}$-ray analysis. Inspection of Fig. 2 confirms the regiochemistry and reveals the molecular structure of the expected 3-bromo-4-fluorofuran. No significant distortion of the furan ring due to the presence of fluorine was

Table 4 Preparation of fluorofurans $\mathbf{7 - 9 ^ { a }}$

\begin{tabular}{llll}
\hline Silyl ether 6 & $\begin{array}{l}\text { Furan 7 } \\
\text { yield [\%] }\end{array}$ & $\begin{array}{l}\text { Bromofuran } \mathbf{8} \\
\text { yield [\%] }\end{array}$ & $\begin{array}{l}\text { Iodofuran 9 } \\
\text { yield [\%] }\end{array}$ \\
\hline a & $95^{23,59}$ & 76 & $62^{25}$ \\
b & 92 & 70 & 78 \\
c & 96 & 68 & 72 \\
d & 94 & 69 & 68 \\
e & 92 & 63 & 65 \\
f & 89 & - & 38 \\
g & 52 & - & - \\
${ }^{a}$ For R, R' see Table 1. & & \\
\hline
\end{tabular}

Table 5 Catalyst optimization: bromocyclization of 2-fluorobutynone $\mathbf{2 a}^{a}$

\begin{tabular}{llccc}
\hline Entry & $\mathrm{AuCl}[\%]$ & $\mathrm{ZnBr}_{2}[\%]$ & $\mathrm{Time}^{b}$ & Yield $^{c}$ \\
\hline 1 & - & - & $10 \mathrm{~min}$ & 10 \\
2 & 5 & - & $10 \mathrm{~min}$ & 16 \\
3 & 5 & - & $1 \mathrm{~h}$ & 19 \\
4 & - & 20 & $10 \mathrm{~min}$ & 43 \\
5 & - & 20 & $15 \mathrm{~min}$ & 47 \\
6 & - & 100 & $11 \mathrm{~h}^{d}$ & $>98$ \\
7 & - & 20 & $10 \mathrm{~min}$ & $97^{e}$ \\
8 & 5 & & $10 \mathrm{~min}$ & $>98$
\end{tabular}

${ }^{a}$ NBS (1.2 equiv), DCM, rt, reaction in $0.05 \mathrm{mmol} \mathrm{scale,} 0.0025 \mathrm{M}$. ${ }^{b}$ Solvent evaporation time not accounted for. ${ }^{c}$ Conversion determined by the ${ }^{19} \mathrm{~F}$ NMR. ${ }^{d}$ The reaction was not monitored throughout the interval. ${ }^{e}$ Complete conversion, product accompanied by an unidentified compound at $\delta-103.0 \mathrm{ppm}\left(3 \%,{ }^{19} \mathrm{~F}\right.$ NMR).

noticed. The entire molecule of $\mathbf{8 a}$ is nearly planar within $0.12 \AA$. The maximum atom deviation from the average plane is $0.25 \AA$ for $\mathrm{C}-16$ and $\mathrm{C}-18$.

The gold-catalyzed formation of furans from propargyl ketones is believed to proceed via an intramolecular, stepwise mechanism (Fig. 3). Since non-terminal alkynes were used in this work, the mechanistic pathway can be illustrated using the coordination of $\mathrm{Au}$ to the carbon-carbon triple bond. The role of zinc is not confirmed at this moment. Although some zinc halides are excellent catalysts for the cycloisomerization of regular alkynones $\mathbf{3},{ }^{24}$ the fluoroalkynones $\mathbf{2}$ are reluctant to proceed under the sole influence of zinc bromide or triflate. The inability of zinc to act on its own as a cyclization catalyst may indicate poor $\pi$-bond activation. We believe that the role of zinc, is to increase enolization of alkynones via coordination to the oxygen atom of a carbonyl group. In electrophilic cyclization another role of the zinc halide would be to accelerate the release of electrophile by enhancement of the dissociation of $N$-halosuccinimide (NXS) into an electrophilic halogen and/or activation of the halogen towards an electrophilic reaction.

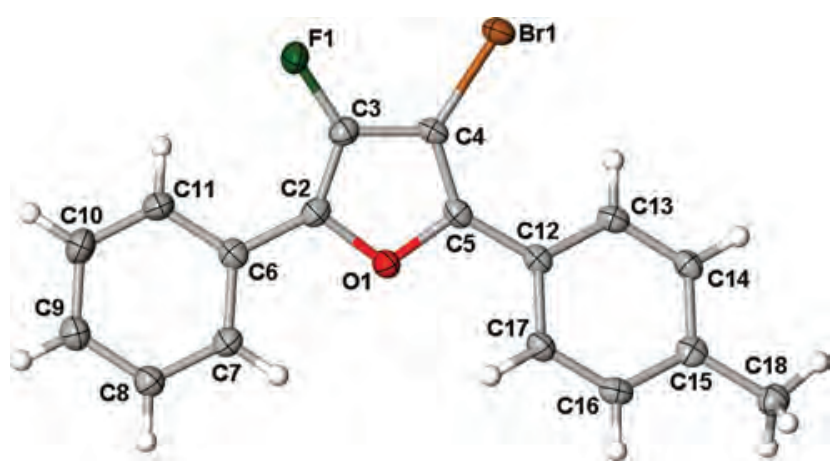

Fig. 2 An ORTEP view of 8a illustrating the atom labeling scheme and thermal ellipsoids (50\% probability level). Selected interatomic distances ( $\AA$ ): F1-C3 1.392(3), Br1-C4 1.877(3), O1-C2 1.379(4), O1-C5 1.378(4), C2-C3 1.353(4), C2-C6 1.453(5), C3-C4 1.408(4), C4-C5 1.358(4), C5-C12 1.451(4). Key angles $\left({ }^{\circ}\right)$ : C2-O1-C5 109.0(2), O1C2-C3 107.0(3), O1-C2-C6 117.5(3), C3-C2-C6 135.5(3), C2-C3-C4 109.0(3), F1-C3-C2 127.1(3), F1-C3-C4 123.9(3), C3-C4-C5 106.9 (3), Br1-C4-C3 123.2(2), Br1-C4-C5 129.8(2), O1-C5-C4 108.1(3), O1-C5-C12 115.4(3), C4-C5-C12 136.5(3). 


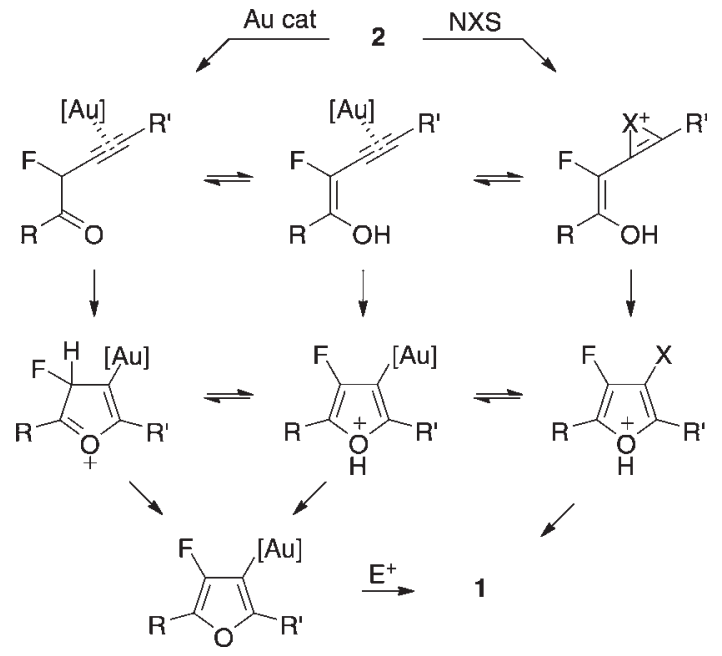

Fig. 3 Mechanistic outline for cyclization of alkynones 2 (electrophile/ ketone pathway omitted).

Electrophilic pathways are believed to proceed via halogen coordination to the triple bond, which could compete with a gold-activated cyclization via $\pi$-bond activation (Fig. 3). As mentioned earlier, gold(I) complexes are known to be effective $\pi$-electrophilic Lewis acids. ${ }^{54}$ Thus the mechanism might include the formation of the intermediate vinylgold species that is subsequently trapped by electrophilic halogens. The presence of zinc might also accelerate protonation/halogenation of such an intermediate. However, the incidence of the reaction (albeit slow) with sole $\mathrm{N}$-iodo- or $\mathrm{N}$-bromosuccinimide, indicates that the electrophilic halogen is capable of acting by itself (Table 5 entry 1 and ref. 25). Also, the lack of non-halogenated fluorofurans formation (within detection limit of ${ }^{1} \mathrm{H}$ NMR), when the cyclization reaction was carried out in the presence of gold/NXS, may suggest that gold may not act as the cyclization catalyst but rather as the activator of the NXS. ${ }^{60}$ It could also be assumed that the gold/electrophilic pathways may be parallel to each other, with presumably the electrophilic cyclization proceeding faster.

Also, a control experiment was conducted to acquire insight into the participation of a direct iodination reaction of the cyclized product in the mechanistic process. A non-halogenated, 3 -fluorofuran 7a was treated with NIS (1.2 equiv) in the presence of $\mathrm{AuCl} / \mathrm{ZnBr}_{2}(5: 20 \mathrm{~mol} \%$, DCM, rt). After $12 \mathrm{~h}$, no iodofuran $7 \mathbf{a}$ was detected in the reaction mixture by GC/MS.

The iodine in furan 9a was utilized to prepare an entirely diverse substituted $\beta$-fluorofurans using cross-coupling reactions. The Sonogashira coupling of 9a gave phenylethynyl fluorofuran 10 with $92 \%$ yield (Scheme 6). The Suzuki-Miyaura coupling reaction with the thiophene-3-boronic acid was confirmed using classical conditions to produce thiophenylfluorofuran 11 with $92 \%$ yield. Lithium $N$-heterocyclic trialkylborates (trialkoxyborates) were introduced shortly before to facilitate the coupling of electron-deficient 2-substituted nitrogen-containing heterocycles. ${ }^{61}$ These organoboron salts, which are commercially available, provide convenience in handling and use. Applying $\mathrm{Cu}(\mathrm{I})$ enhanced the coupling reaction conditions, ${ }^{62,63}$ the use of lithium (pyridin-2-yl)triisopropoxyborate allowed for the introduction of a conventionally unreactive moiety (Scheme 6).

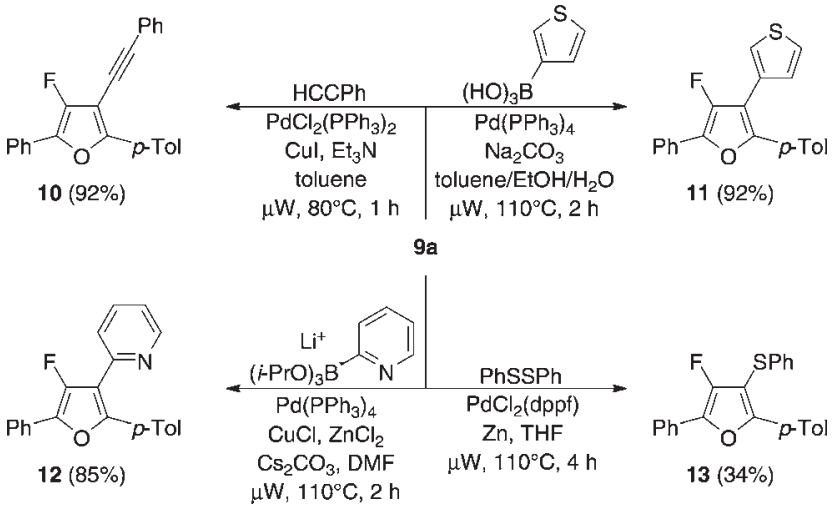

Scheme 6 Cross-coupling reactions of 3-fluoro-4-iodofuran 9a.

Pyridinyl-substituted fluorofuran $\mathbf{1 2}$ was obtained in $85 \%$ yields. The coupling with disulfane (diphenyl disulfide), carried out in reductive conditions, ${ }^{64}$ produced phenylthio furan $\mathbf{1 3}$ with poor yield (34\%). All the couplings required elevated temperature that was effected by microwaves assistance. The established conditions $\left(80-110{ }^{\circ} \mathrm{C}, 1-4 \mathrm{~h}\right)$ are comparable to the coupling of other $\beta$-iodofurans $\left(90^{\circ} \mathrm{C}, 24 \mathrm{~h}\right.$ or $\left.110^{\circ} \mathrm{C}, 0.5-2 \mathrm{~h}\right) .^{7,9}$

Phenylalkynyl fluorofuran $\mathbf{1 0}$ gave crystals suitable for study by X-ray diffraction, which confirmed the structure (Fig. 4). The crystal structure of $\mathbf{1 0}$ shows molecules with nearly planar conformations within $0.40 \AA$. The maximum atom deviations from

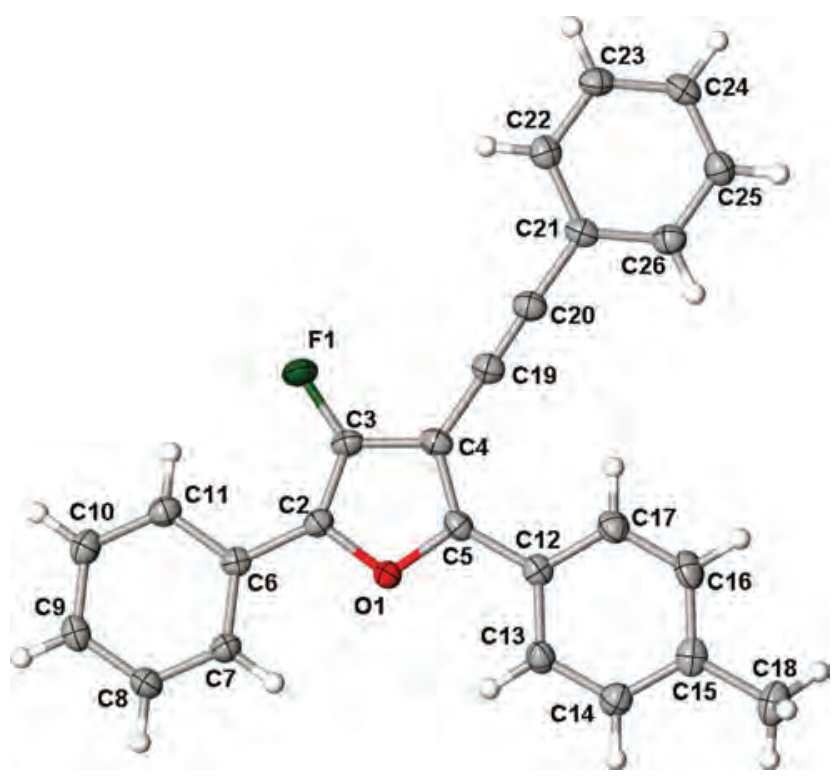

Fig. 4 An ORTEP view of the $\mathbf{1 0}$ illustrating atom labeling scheme and thermal ellipsoids (50\% probability level). Selected interatomic distances (§): F1-C3 1.3448(19), O1-C2 1.378(2), O1-C5 1.371(2), C2C3 1.351(2), C2-C6 1.450(2), C3-C4 1.415(3), C4-C5 1.379(2), C4C19 1.423(2), C5-C12 1.454(2), C19-C20 1.198(2), C20-C21 1.436 (2). Key angles $\left({ }^{\circ}\right)$ : C2-O1-C5 108.52(13), O1-C2-C3 107.18(14), O1-C2-C6 118.09(14), C3-C2-C6 134.73(16), C2-C3-C4 110.13(15), F1-C3-C2 125.96(16), F1-C3-C4 123.91(15), C3-C4-C5 104.71(15), C3-C4-C19 125.91(16), C5-C4-C19 129.38(17), O1-C5-C4 109.46 (15), O1-C5-C12 116.19(14), C4-C5-C12 134.35(16), C4-C19-C20 177.8(2), C19-C20-C21 178.0(2). 
the average plane are 0.10 and $0.11 \AA$ for $\mathrm{C}-23$ and $\mathrm{C}-26$, respectively.

New 3-fluorofurans 7-13 (Table 4) were characterized by ${ }^{1} \mathrm{H}$, ${ }^{13} \mathrm{C}$, and ${ }^{19} \mathrm{~F}$ NMR, IR, (HR)MS. The characteristic ${ }^{1} \mathrm{H}$ NMR features for fluorofurans $\mathbf{7 a}-\mathbf{g}$ include the $\mathrm{H}-4$ signals (doublets 7.08-6.28 ppm with $J_{\mathrm{HF}} 0.7-1.2 \mathrm{~Hz}$ ). C-F carbons gave rise in ${ }^{13} \mathrm{C}$ NMR to doublets 153.1-150.2, $J_{\mathrm{CF}} 243.4-255.6 \mathrm{~Hz}$ for fluorofurans 7 and $149.2-148.0 / 152.2-150.8 \mathrm{ppm} \quad\left(J_{\mathrm{CF}}\right.$ 252.0-253.4/250.1-251.7 Hz) for bromo/iodofurans 8/9, respectively. Longer range couplings, including ${ }^{4} J_{\mathrm{CF}}$, were observed. ${ }^{19}$ The neighboring $\beta$-carbons ( $\delta$ 100.0-99.0/89.9-89.6/ 57.4-56.9 ppm) showed ${ }^{2} J_{\mathrm{CF}} 20.1-20.6 / 21.3-21.6 / 24.8-25.1 \mathrm{~Hz}$ for $7 / 8 / 9$, respectively. Observed ${ }^{19} \mathrm{~F}$ NMR signals for atoms attached to the furan ring were in a close range (163.0-158.9, 163.8-160.8, 159.0-155.3 ppm, 7/8/9). Mass spectra for 7-13 exhibited intense molecular ion peaks and appropriate isotopic patterns. Accurate elemental analyses and/or HRMS spectra were obtained.

\section{Conclusion}

In summary, we have demonstrated that Z-butenynyl silyl ethers 6 can be successfully accessed from butynones $\mathbf{3}$, and their monofluorination with Selectfluor leads to 2-fluorobutynones 2. Furthermore, 2-fluorobutynones $\mathbf{2}$ undergo cycloisomerization in the presence of chlorotriphenylphosphine gold/silver trifluoromethanesulfonate and halocyclization becomes effective when $N$-halosuccinmides are used in combination with gold(I) chloride/zinc bromide. The synthetic method proved to be best suited for aryl substituents at $\alpha-(\mathrm{C}-2$ and $\mathrm{C}-5)$ furan positions. This way 3-fluoro-, 3,4-bromofluoro-, and 3,4-fluoroiodofurans 7, 8, and 9 were obtained with good yields and characterized. The relatively short reaction times $(10 \mathrm{~min})$ and mild conditions (rt) provide an appealing alternative to the currently available methods, also from the standpoint of halogen atom economy. These methods avoid the loss of halogens in the synthetic pathway, facilitate the regioselective introduction of fluorine within two available $\beta$ positions, and also allows for the introduction of substituents such as cycloalkyls that are not easily carried out by other methods. However, due to the stability of aryl substituted alkynones the method is best suited for compounds with aryl substituents. The dual catalyst methodology proves the mild Lewis acid aids the cyclization catalyzed by the gold catalyst. Additionally, difluorobutynones 4 were prepared by direct fluorination of ketones $\mathbf{3}$.

\section{Experimental section}

\section{General experimental details}

Dichloromethane was collected from the Innovative Technology PS-MD-6 solvent purification system. $N$-bromosuccinimide (Avocado) was recrystallized from water. Other reagents were used as received. Column chromatography was carried out on silica gel (Dynamic Adsorbents, 32-63 $\mu$ ). The NMR chemical shifts are reported: ${ }^{1} \mathrm{H}(400 \mathrm{MHz})$ and ${ }^{13} \mathrm{C}(101 \mathrm{MHz})$ relative to $\mathrm{CDCl}_{3}$ /acetone- $d_{6}, 7.26 / 2.05 \mathrm{ppm}$ and $77.16 / 29.9 \mathrm{ppm}$ respectively, and ${ }^{19} \mathrm{~F}(376 \mathrm{MHz})$ relative to $\mathrm{CFCl}_{3}$ as external standard. The microwave reactions were carried out using capped vials in a Biotage Initiator reactor equipped with a conventional temperature IR sensor.

\section{2,2-Difluoro-4-(4-methylphenyl)-1-phenyl-but-3-yn-1-one (4a)}

An oven-dried round-bottom flask was charged with 3a (0.070 g, $0.30 \mathrm{mmol})$, L-proline $(6.9 \mathrm{mg}, 0.060 \mathrm{mmol})$, Selectfluor $(0.250 \mathrm{~g}, 0.700 \mathrm{mmol})$, and ground $5 \AA$ molecular sieves $(0.50 \mathrm{~g})$. Anhydrous acetonitrile $(6 \mathrm{~mL})$ was injected through the septum. The reaction was stirred at ambient temperature under nitrogen and monitored by ${ }^{19} \mathrm{~F}$ NMR. The reaction was judged to be complete after 7 days, when mono-fluorinated ketone only existed in trace amounts. The mixture was diluted with ether $(\sim 60 \mathrm{~mL})$ and filtered through a Bücher funnel. The filter cake was washed with ether $(20 \mathrm{~mL})$. The combined filtrate was stirred with $1 \mathrm{~N} \mathrm{HCl}(10 \mathrm{~mL})$ for $1 \mathrm{~h}$. The organic layer was separated, dried over $\mathrm{MgSO}_{4}$, filtered and concentrated. Silica gel chromatography (hexane/ethyl acetate $30: 1$ ) gave $\mathbf{4 a}$ as a yellow oil $(0.051 \mathrm{~g}, 0.19 \mathrm{mmol}, 63 \%)$. IR $\left(v, \mathrm{~cm}^{-1}\right.$, film) 2925, 1734, 1718,1653 , 1559. HRMS (DART-TOF) $[\mathrm{M}+\mathrm{H}]^{+}$calcd for $\mathrm{C}_{17} \mathrm{H}_{13} \mathrm{~F}_{2} \mathrm{O}$ 271.0935. Found 271.0929. NMR $\left(\mathrm{CDCl}_{3}, \delta, \mathrm{ppm}\right)$ : ${ }^{1} \mathrm{H} 8.23(\mathrm{~d}, J=8.3 \mathrm{~Hz}, 2 \mathrm{H}), 7.70-7.64(\mathrm{~m}, 1 \mathrm{H}), 7.58-7.50(\mathrm{~m}$, 2H), $7.38(\mathrm{~d}, J=8.0 \mathrm{~Hz}, 2 \mathrm{H}), 7.16(\mathrm{~d}, J=8.0 \mathrm{~Hz}, 2 \mathrm{H}), 2.37(\mathrm{~s}$, $3 \mathrm{H}) ;{ }^{13} \mathrm{C} 184.9(\mathrm{t}, J=30.7 \mathrm{~Hz}), 134.8,133.2,132.4(\mathrm{t}, J=2.5$ $\mathrm{Hz}), 130.6(\mathrm{t}, J=2.0 \mathrm{~Hz}), 129.5,128.9,125.7,116.5(\mathrm{t}, J=2.9$ $\mathrm{Hz}), 108.4(\mathrm{t}, J=243.7 \mathrm{~Hz}), 93.4(\mathrm{t}, J=6.8 \mathrm{~Hz}), 79.1(\mathrm{t}, J=$ $38.2 \mathrm{~Hz}), 21.9 ;{ }^{19} \mathrm{~F}-88.0$.

\section{1-(4-Bromophenyl)-4-(4-(tert-butyl)phenyl)-2,2-difluorobut-3-yn- 1-one (4e)}

Procedure analogous to 4a: From 3e (0.107 g, $0.300 \mathrm{mmol})$; $4 \mathrm{e}$ was obtained as a yellow solid $(0.078 \mathrm{~g}, 0.20 \mathrm{mmol}, 67 \%)$. IR $\left(v, \mathrm{~cm}^{-1}\right.$, film) 2925, 2234, 1718, 1653, 1559. HRMS (DART-TOF) Calcd for $[\mathrm{M}+\mathrm{H}]^{+} \mathrm{C}_{20} \mathrm{H}_{18} \mathrm{BrF}_{2} \mathrm{O} 391.0509$. Found 391.0522. NMR $\left(\mathrm{CDCl}_{3}, \delta, \mathrm{ppm}\right):{ }^{1} \mathrm{H} 8.09\left(\mathrm{AA}^{\prime} \mathrm{XX}^{\prime}, J \approx\right.$ $8.7 \mathrm{~Hz}, 2 \mathrm{H}),{ }^{65} 7.68\left(\mathrm{AA}^{\prime} \mathrm{XX}^{\prime}, J \approx 8.7 \mathrm{~Hz}, 2 \mathrm{H}\right),{ }^{65} 7.42\left(\mathrm{AA}^{\prime} \mathrm{XX}^{\prime}\right.$, $J \approx 8.3 \mathrm{~Hz}, 2 \mathrm{H}),{ }^{65} 7.38\left(\mathrm{AA}^{\prime} \mathrm{XX}^{\prime}, J \approx 8.3 \mathrm{~Hz}, 2 \mathrm{H}\right),{ }^{65} 1.31(\mathrm{~s}$, $9 \mathrm{H}) ;{ }^{13} \mathrm{C} 184.0(\mathrm{t}, J=30.8 \mathrm{~Hz}), 154.6,132.4,132.3(\mathrm{t}, J=2.4$ $\mathrm{Hz}), 132.0(\mathrm{t}, J=2.0 \mathrm{~Hz}), 130.5,130.0,125.9,116.3(\mathrm{t}, J=2.9$ $\mathrm{Hz}), 108.2(\mathrm{t}, J=244.0 \mathrm{~Hz}), 93.8(\mathrm{t}, J=6.6 \mathrm{~Hz}), 78.8(\mathrm{t}, J=$ $38.2 \mathrm{~Hz}), 35.3,31.3 ;{ }^{19} \mathrm{~F}-88.2$.

\section{Preparation of silyl ethers (6)}

Procedures A and B. The flask was charged with homopropargyl alcohol 5a $(1.42 \mathrm{~g}, 6.00 \mathrm{mmol})$ and acetone $(30 \mathrm{~mL})$. Jones reagent $(3.0 \mathrm{M}, 3.0 \mathrm{~mL}, 9.0 \mathrm{mmol})$ was added at $0{ }^{\circ} \mathrm{C}$ (water/ice bath). The reaction was stirred for $20 \mathrm{~min}$ at ambient temperature, quenched with $i \mathrm{PrOH}(2.0 \mathrm{~mL})$, and concentrated under vacuum. The residue was diluted with ether $(100 \mathrm{~mL})$ and filtered through a Büchner funnel. The filter cake was rinsed with ether $(2 \times 20 \mathrm{~mL})$. The combined organic solutions were washed with brine $(20 \mathrm{~mL}), 5 \% \mathrm{NaHCO}_{3}(20 \mathrm{~mL})$, dried over $\mathrm{MgSO}_{4}$, and concentrated to yield the ketone $\mathbf{3 a}$ as a yellow solid which was used for the next step without further purification. The flask containing the crude ketone 3a was charged with anhydrous THF $(30 \mathrm{~mL})$ under nitrogen. LDA $(2.0 \mathrm{M}$, 
$3.6 \mathrm{~mL}, 7.2 \mathrm{mmol}$ ) was added dropwise at $-78{ }^{\circ} \mathrm{C}$ and the reaction was stirred for 20 min followed by addition (for procedure $\mathrm{B}$ only) of anhydrous TMEDA $(1.80 \mathrm{~mL}, 12.0 \mathrm{mmol})$. The reaction was stirred at $-78{ }^{\circ} \mathrm{C}$ for $10 \mathrm{~min}$ and TBSCl $(1.08 \mathrm{~g}$, $7.20 \mathrm{mmol})$ in anhydrous THF $(30 \mathrm{~mL})$ was injected in small portions. The reaction was stirred at ambient temperature for $12 \mathrm{~h}$. After concentration under vacuum, silica gel column chromatography (hexane/ethyl acetate $50: 1$ ) gave silyl ether $\mathbf{6 a}$ as a white solid (1.23 g, $3.53 \mathrm{mmol}, 60 \%)$.

Procedure C. To the homopropargyl alcohol 5b (1.12 g, $6.00 \mathrm{mmol})$ in acetone $(30 \mathrm{~mL})$ Jones reagent $(3.0 \mathrm{M}, 3.0 \mathrm{~mL}$, $9.0 \mathrm{mmol}$ ) was added at $0{ }^{\circ} \mathrm{C}$. The reaction was stirred for $20 \mathrm{~min}$ at ambient temperature. The reaction was quenched with $i \mathrm{PrOH}(2 \mathrm{~mL})$ and concentrated under vacuum. The residue was diluted with ether $(80 \mathrm{~mL})$ and filtered through a Büchner funnel. The filter cake was rinsed with ether $(2 \times 20 \mathrm{~mL})$. The combined organic solutions were washed with brine $(20 \mathrm{~mL})$ and $5 \% \mathrm{NaHCO}_{3}(20 \mathrm{~mL})$. The filtrate was dried over $\mathrm{MgSO}_{4}$, filtered and concentrated to yield the propargyl ketone as a yellow oil, which was used for the next step without further purification. The flask containing the propargyl ketone was charged with $\mathrm{NaI}(0.300 \mathrm{~g}, 2.00 \mathrm{mmol})$ and TBSCl $(0.990 \mathrm{~g}$, $6.60 \mathrm{mmol}$ in glovebox). Anhydrous acetonitrile $(30 \mathrm{~mL})$ was injected through the septum. To the above homogeneous solution DBU $\left(0.99 \mathrm{~mL}, 6.6 \mathrm{mmol}\right.$ ) was added dropwise at $0{ }^{\circ} \mathrm{C}$ (water/ ice bath). The reaction mixture was stirred at $0{ }^{\circ} \mathrm{C}$ for $4 \mathrm{~h}$ (TLC). After concentration under vacuum, silica gel column chromatography (hexane) gave $\mathbf{6 b}$ as a yellow oil $(1.07 \mathrm{~g}, 3.58 \mathrm{mmol}$, $60 \%)$.

tert-Butyldimethyl\{[4-(4-methylphenyl)-1-phenylbut-1-en-3yn-1-yl]oxy\}silane (6a). Procedure B. Obtained 6a as a white solid, a mixture of $E / Z$ isomers in a $13: 87$ ratio. ${ }^{46}$ Calcd for $\mathrm{C}_{23} \mathrm{H}_{28}$ OSi: C, 79.26; H, 8.10. Found: C, 79.45; H, 8.51. IR ( $v$, $\left.\mathrm{cm}^{-1}, \mathrm{KBr}\right) 2927,2856,2186,1349,1103,816,787,765,694$. UV-vis $\left(\varepsilon, \mathrm{M}^{-1} \mathrm{~cm}^{-1}\right.$; ether; $\left.3.6 \times 10^{-5} \mathrm{M}\right) 227(17000)$, 314 (28 000). MS (EI, $m / z): 348\left(30 \%, \mathrm{M}^{+}\right), 291(100 \%$, $\left.[\mathrm{M}-t \mathrm{Bu}]^{+}\right)$. NMR $\left(\mathrm{CDCl}_{3}, \delta, \mathrm{ppm}\right):{ }^{1} \mathrm{H} 8.04-7.99(\mathrm{~m}, 0.28 \mathrm{H})$, 7.58-7.52 (m, 1.72H), 7.42-7.31 (m, 5H), 7.16-7.09 (m, 2H), 5.59 (s, $0.86 \mathrm{H}, Z$-isomer), 5.38 (s, $0.14 \mathrm{H}, E$-isomer), 2.36 (s, $2.58 \mathrm{H}), 2.35$ (s, $0.42 \mathrm{H}), 1.03$ (s, 7.74H, Z-isomer), 1.00 (s, $1.26 \mathrm{H}, E$-isomer), 0.21 (s, $0.84 \mathrm{H}, E$-isomer), 0.17 (s, $5.16 \mathrm{H}$, $Z$-isomer); ${ }^{13} \mathrm{C}\left\{{ }^{1} \mathrm{H}\right\}$ (signals for $Z$-isomer) $160.0,138.2,138.0$, $131.3,129.3,129.0,128.4,126.0,121.4,94.4,91.0,86.8,26.1$, $21.7,18.8,-3.6$.

tert-Butyl[(4-cyclopropyl-1-phenylbut-1-en-3-yn-1-yl)oxy] dimethylsilane (6b). Procedure $\mathrm{C}$. Obtained $\mathbf{6 b}$ as a yellow oil, a mixture of $E / Z$ isomers in a $8: 92$ ratio. ${ }^{46}$ Calcd for $\mathrm{C}_{19} \mathrm{H}_{26} \mathrm{OSi}$ : C, 76.45; H, 8.78. Found: C, 76.27; H, 8.70. IR ( $v, \mathrm{~cm}^{-1}$, film) 2930, 2858, 2217, 1339, 1257, 1088, 841, 783, 763, 695. MS (EI, $m / z): 298\left(20 \%, \mathrm{M}^{+}\right), 241\left(100 \%,[\mathrm{M}-t \text {-Bu }]^{+}\right) . \mathrm{NMR}$ $\left(\mathrm{CDCl}_{3}, \delta, \mathrm{ppm}\right):{ }^{1} \mathrm{H}$ 7.52-7.43 (m, 2H), 7.34-7.28 (m, 3H), $5.31(\mathrm{~d}, J=1.8 \mathrm{~Hz}, 0.92 \mathrm{H}, Z$-isomer $), 5.14(\mathrm{~d}, J=2.0 \mathrm{~Hz}$, $0.08 \mathrm{H}, E$-isomer), $1.49-1.34$ (m, 1H), 1.01 (s, $8.30 \mathrm{H}, \mathrm{Z}$-isomer), 0.97 (s, $0.70 \mathrm{H}, E$-isomer), 0.86-0.74 (m, 4H), $0.16(\mathrm{~s}, 0.51 \mathrm{H}$, E-isomer), 0.13 (s, 5.49H, Z-isomer); ${ }^{13} \mathrm{C}\left\{{ }^{1} \mathrm{H}\right\}$ (signals for $Z$-isomer) 159.6, 138.3, 128.8, 128.3, 125.8, 98.2, 91.1, 73.5, $26.0,18.7,8.5,0.90,-3.6$.
tert-Butyl(\{[1-(4-fluorophenyl)-4-(4-methylphenyl)but-1-en-3yn-1-yl]oxy\})dimethylsilane (6c). Procedure C. From 5c (1.52 g, $6.00 \mathrm{mmol})$. Obtained $\mathbf{6 c}(1.14 \mathrm{~g}, 3.12 \mathrm{mmol}, 52 \%)$ as a white solid, a mixture of $E / Z$ isomers in a $2: 98$ ratio. ${ }^{46}$ Calcd for $\mathrm{C}_{23} \mathrm{H}_{27} \mathrm{FOSi}$ : C, 75.37; H, 7.42. Found: C, 75.55; H, 7.57. IR ( $v$, $\left.\mathrm{cm}^{-1}, \mathrm{KBr}\right) 2955,2856,2189,1506,1104,816,784$. UV-vis $(\varepsilon$, $\mathrm{M}^{-1} \mathrm{~cm}^{-1}$; ether; $3.7 \times 10^{-5}$ M) 226 (16 000), 313 (29 000). MS $(\mathrm{EI}, \mathrm{m} / \mathrm{z}): 366\left(30 \%, \mathrm{M}^{+}\right), 309\left(100 \%, \mathrm{M}^{+}-t \mathrm{Bu}\right)$. NMR $\left(\mathrm{CDCl}_{3}, \delta, \mathrm{ppm}\right):{ }^{1} \mathrm{H} 7.56-7.50(\mathrm{~m}, 2 \mathrm{H}), 7.35$ (dt, $J=8.1,1.6$ $\mathrm{Hz}, 2 \mathrm{H}), 7.13$ (d, $J=8.1 \mathrm{~Hz}, 2 \mathrm{H}), 7.07-7.00$ (m, 2H), 5.52 (s, $0.98 \mathrm{H}, Z$-isomer), 5.31 (s, $0.02 \mathrm{H}, E$-isomer), 2.36 (s, $3 \mathrm{H}), 1.02$ (s, 9H), 0.21/0.17 Z/E (s, 6H); ${ }^{13} \mathrm{C}\left\{{ }^{1} \mathrm{H}\right\}$ (signals for $Z$-isomer) $163.3(\mathrm{~d}, J=248.6 \mathrm{~Hz}), 159.0,138.0,134.4(\mathrm{~d}, J=3.2 \mathrm{~Hz})$, $131.3,129.3,127.7(\mathrm{~d}, J=8.3 \mathrm{~Hz}), 121.3,115.4(\mathrm{~d}, J=21.7$ Hz), 94.4, 90.8, 86.6, 26.0, 21.7, 18.7, -3.5.

\{[1-(4-Bromophenyl)-4-(4-methylphenyl)but-1-en-3-yn-1-yl] oxy\}(tert-butyl)dimethylsilane (6d). Procedure B. From 5d $(1.88 \mathrm{~g}, 6.00 \mathrm{mmol})$. Obtained $\mathbf{6 d}(1.58 \mathrm{~g}, 3.70 \mathrm{mmol}, 62 \%)$ as a white solid, a mixture of $E / Z$ isomers in a $2: 98$ ratio. ${ }^{46}$ Calcd for $\mathrm{C}_{23} \mathrm{H}_{27} \mathrm{BrOSi}$ : C, 64.63; $\mathrm{H}, 6.37$. Found: $\mathrm{C}, 64.88 ; \mathrm{H}, 6.40$. IR $\left(v, \mathrm{~cm}^{-1}, \mathrm{KBr}\right) 2927,2858,1484,894,784$. UV-vis $(\varepsilon$, $\mathrm{M}^{-1} \mathrm{~cm}^{-1}$; ether; $\left.3.2 \times 10^{-5} \mathrm{M}\right) 230$ (17 000), 319 (37000). MS $(\mathrm{EI}, \mathrm{m} / z): 426\left(20 \%, \mathrm{M}^{+}\right), 369\left(100 \%, \mathrm{M}^{+}-t \mathrm{Bu}\right) . \mathrm{NMR}$ $\left(\mathrm{CDCl}_{3}, \delta, \mathrm{ppm}\right):{ }^{1} \mathrm{H} 7.48(\mathrm{dt}, J=8.8,2.0 \mathrm{~Hz}, 2 \mathrm{H}), 7.41(\mathrm{dt}, J=$ $8.8,2.0 \mathrm{~Hz}, 2 \mathrm{H}), 7.35$ (d, $J=8.0 \mathrm{~Hz}, 2 \mathrm{H}), 7.14$ (d, $J=8.0 \mathrm{~Hz}$, $2 \mathrm{H}), 5.58$ (s, $0.98 \mathrm{H}, Z$-isomer), 5.39 (s, $0.02 \mathrm{H}, E$-isomer), 2.36 (s, 3H), 1.02 (s, 8.82H, Z-isomer), 0.99 (s, $0.18 \mathrm{H}, E$-isomer), 0.21 (s, $0.12 \mathrm{H}, E$-isomer), 0.18 (s, $5.88 \mathrm{H}, Z$-isomer); ${ }^{13} \mathrm{C}\left\{{ }^{1} \mathrm{H}\right\}$ (signals for $Z$-isomer) 158.8, 138.2, 137.1, 131.6, 131.3, 129.3, 127.4, 123.1, 121.2, 94.9, 91.5, 86.5, 26.0, 21.7, 18.7, -3.5.

\{[1-(4-Bromophenyl)-4-(4-tert-butylphenyl)but-1-en-3-yn-1-yl] oxy\}(tert-butyl)dimethylsilane (6e). Procedure B. From 5e $(2.14 \mathrm{~g}, 6.00 \mathrm{mmol})$. Obtained $6 \mathrm{e}(1.92 \mathrm{~g}, 4.08 \mathrm{mmol}, 68 \%)$ as a white solid, a mixture of $E / Z$ isomers in a $6: 94$ ratio. ${ }^{46}$ Calcd for $\mathrm{C}_{26} \mathrm{H}_{33}$ BrOSi: C, 66.51; H, 7.08. Found: C, 66.61; H, 7.08. IR $\left(v, \mathrm{~cm}^{-1}, \mathrm{KBr}\right) 2929,2855,2195,1252,1093,1009,894$, 835, 784. UV-vis $\left(\varepsilon, \mathrm{M}^{-1} \mathrm{~cm}^{-1}\right.$; ether; $\left.3.2 \times 10^{-5} \mathrm{M}\right) 228$ $(20000)$ sh, 320 (37 000). MS (EI, $m / z): 470\left(20 \%, \mathrm{M}^{+}\right), 413$ $\left(100 \%, \mathrm{M}^{+}-t \mathrm{Bu}\right)$. NMR $\left(\mathrm{CDCl}_{3}, \delta, \mathrm{ppm}\right):{ }^{1} \mathrm{H} 7.54-7.31(\mathrm{~m}$, $8 \mathrm{H}), 5.59$ (s, $0.94 \mathrm{H}, Z$-isomer), 5.40 (s, $0.06 \mathrm{H}, E$-isomer), 1.33 (s, 9H), 1.03 (s, 8.46H, Z-isomer), 0.99 (s, $0.54 \mathrm{H}, E$-isomer), 0.21 (s, $0.36 \mathrm{H}, E$-isomer), 0.19 (s, 5.64H, Z-isomer); ${ }^{13} \mathrm{C}\left\{{ }^{1} \mathrm{H}\right\}$ (signals for $Z$-isomer) 158.7, 151.3, 137.2, 131.6, 131.1, 127.4, $125.5,123.1,121.2,95.0,91.6,86.5,35.0,31.4,26.0,18.7$, -3.5 .

tert-Butyldimethyl\{[4-(4-methylphenyl)-1-[4-(trifluoromethyl) phenyl]but-1-en-3-yn-1-yl]oxy\}silane (6f). Procedure B. From 5f (0.610 g, $2.00 \mathrm{mmol})$. Obtained 6f (0.510 g, $1.22 \mathrm{mmol}, 61 \%)$ as a white solid, a mixture of $E / Z$ isomers in a $3: 97$ ratio. $^{46}$ Calcd for $\mathrm{C}_{24} \mathrm{H}_{27} \mathrm{~F}_{3} \mathrm{OSi}$ : C, 69.20; H, 6.53. Found: C, 69.43; $\mathrm{H}$, 6.67. IR $\left(v, \mathrm{~cm}^{-1}, \mathrm{KBr}\right) 2930,1323,1125,1068,814,781$. UVvis $\left(\varepsilon, \mathrm{M}^{-1} \mathrm{~cm}^{-1}\right.$; ether; $\left.3.3 \times 10^{-5} \mathrm{M}\right) 225$ (20000), 323 (29 000). MS (EI, m/z): $416\left(10 \%, \mathrm{M}^{+}\right), 359\left(100 \%, \mathrm{M}^{+}-t \mathrm{Bu}\right)$. $\mathrm{NMR}\left(\mathrm{CDCl}_{3}, \delta, \mathrm{ppm}\right):{ }^{1} \mathrm{H} 7.66(\mathrm{~d}, J=8.4 \mathrm{~Hz}, 2 \mathrm{H}), 7.61(\mathrm{~d}, J=$ $8.4 \mathrm{~Hz}, 2 \mathrm{H}), 7.36$ (d, $J=8.0 \mathrm{~Hz}, 2 \mathrm{H}), 7.15$ (d, $J=8.0 \mathrm{~Hz}, 2 \mathrm{H})$, $5.68(\mathrm{~s}, 0.97 \mathrm{H}, Z$-isomer $), 5.48(\mathrm{~s}, 0.03 \mathrm{H}, E$-isomer $), 2.37$ (s, $3 \mathrm{H}), 1.03$ (s, 8.73H, Z-isomer), 1.00 (s, $0.27 \mathrm{H}, E$-isomer), 0.23 
(s, 0.18H, E-isomer), 0.19 (s, 5.82H, Z-isomer); ${ }^{13} \mathrm{C}\left\{{ }^{1} \mathrm{H}\right\}$ (signals for $Z$-isomer) $158.2,141.6,138.4,131.4,130.8$ (q, $J=32.5 \mathrm{~Hz}$ ), $129.4,126.0,125.5$ (q, $J=3.8 \mathrm{~Hz}), 124.3$ (q, $J=271.8 \mathrm{~Hz}$ ), $121.0,95.6,92.9,86.2,26.0,21.7,18.7,-3.5$.

tert-Butyldimethyl[(6-phenylhex-3-en-5-yn-3-yl)oxy]silane (6g). Procedure A. From 5g (1.05 g, $6.03 \mathrm{mmol})$. Silica gel was washed with $1 \% \mathrm{Et}_{3} \mathrm{~N} / \mathrm{eluent}(\mathrm{v} / \mathrm{v})$. Obtained $\mathbf{6 g} \quad(1.18 \mathrm{~g}$, $4.12 \mathrm{mmol}, 68 \%$ ) as a yellow oil, a mixture of $E / Z$ isomers in a $89: 11$ ratio. $^{46}$ IR $\left(v, \mathrm{~cm}^{-1}\right.$, film) $2931,2859,2201,1594,1490$, 1293, 871, 840. MS (EI, $m / z): 286\left(10 \%, \mathrm{M}^{+}\right), 229(100 \%$, [M - $\left.t \mathrm{Bu}]^{+}\right)$. NMR $\left(\mathrm{CDCl}_{3}, \delta, \mathrm{ppm}\right):{ }^{1} \mathrm{H} 7.42-7.38(\mathrm{~m}, 2 \mathrm{H})$, 7.33-7.24 (m, 3H), 4.93 (s, 0.11 H, Z-isomer), 4.89 (s, $0.89 \mathrm{H}$, $E$-isomer), 2.48 (q, $J=7.5 \mathrm{~Hz}, 2 \mathrm{H}), 1.13(\mathrm{t}, J=7.5 \mathrm{~Hz}, 3 \mathrm{H})$, 0.96 (s, 9H), $0.22(\mathrm{~s}, 6 \mathrm{H}) ;{ }^{13} \mathrm{C} 168.4,131.1,128.5,127.4,124.7$, $91.7,87.5,87.3,27.5,25.8,18.4,11.6,-4.3$.

tert-Butyldimethyl\{[5-(4-methylphenyl)-1-phenoxypent-2-en4-yn-2-yl]oxy\}silane (6h). Procedure C. From 5h (1.60 g, $6.00 \mathrm{mmol})$. Obtained $\mathbf{6 h}(1.26 \mathrm{~g}, 3.30 \mathrm{mmol}, 55 \%)$ as a yellow solid, a mixture of $E / Z$ isomers in a $22: 78$ ratio. ${ }^{46}$ Calcd for $\mathrm{C}_{24} \mathrm{H}_{30} \mathrm{O}_{2} \mathrm{Si}$ : C, 76.14; H, 7.99. Found: C, 76.08; H, 8.11. IR ( $v$, $\left.\mathrm{cm}^{-1}, \mathrm{KBr}\right) 2929,2857,2198,1378,1237$. MS (EI, $\left.m / z\right): 378$ $\left(30 \%, \mathrm{M}^{+}\right), 229(100 \%)$. NMR $\left(\mathrm{CDCl}_{3}, \delta, \mathrm{ppm}\right):{ }^{1} \mathrm{H} 7.36-7.29$ $(\mathrm{m}, 4 \mathrm{H}), 7.12(\mathrm{~d}, J=8.0 \mathrm{~Hz}, 2 \mathrm{H}), 7.04-6.91(\mathrm{~m}, 3 \mathrm{H}), 5.32$ (s, $0.78 \mathrm{H}, \mathrm{Z}$-isomer), 5.23 (s, 0.22H, E-isomer), 4.84 (s, 0.44H, Eisomer), $4.44(\mathrm{~s}, 1.56 \mathrm{H}, Z$-isomer), $2.36(\mathrm{~s}, 3 \mathrm{H}), 1.01(\mathrm{~s}, 6.85 \mathrm{H}$, $Z$-isomer), 0.93 (s, 2.15H, E-isomer), 0.32 (s, 4.49H, Z-isomer), 0.17 (s, 1.51H, E-isomer); ${ }^{13} \mathrm{C}\left\{{ }^{1} \mathrm{H}\right\}$ (signals for $Z$-isomer) 158.4, 157.0, 138.0, 131.3, 129.8, 129.3, 121.5,121.2, 114.9, 93.3, $90.9,85.2,69.1,25.9,21.7,18.6,-3.5$.

\section{2-Fluoroalk-3-yn-1-ones (2): general procedure}

A $100 \mathrm{~mL}$ round-bottom flask was charged with ether 6 (0.500 mmol), Selectfluor $(0.195 \mathrm{~g}, 0.550 \mathrm{mmol})$, and acetonitrile $(10 \mathrm{~mL})$. The mixture was stirred at ambient temperature $\left(22{ }^{\circ} \mathrm{C}\right.$ ) and monitored by TLC (hexane/EtOAc $8: 2$; usually for $1 \mathrm{~h})$. Solvent was removed by rotary evaporation and the residue was kept under oil pump vacuum for $30 \mathrm{~min}$. DCM $(60 \mathrm{~mL})$ was added and the mixture was stirred for $10 \mathrm{~min}$. The solid was filtered off (fritted funnel) and the filter cake was washed with DCM $(20 \mathrm{~mL})$. Solvent was removed from the combined filtrates by rotary evaporation to give crude $\mathbf{2}$.

4-Cyclopropyl-2-fluoro-1-phenylbut-3-yn-1-one (2b). NMR $\left(\mathrm{CDCl}_{3}, \delta, \mathrm{ppm}\right):{ }^{1} \mathrm{H}$ 8.12-8.05 (m, 2H), 7.66-7.60 (m, 1H), 7.54-7.48 (m, 2H), $5.98(\mathrm{dd}, J=49.5,2.1 \mathrm{~Hz}, 1 \mathrm{H}), 1.35-1.24$ (m, 1H), 0.86-0.69 (m, 4H); ${ }^{19} \mathrm{~F}-177.8$ (d, $\left.J=49.5 \mathrm{~Hz}\right)$.

\section{3-Fluorofurans (7): general procedure}

Crude 2 (obtained from 6 as described above) was dissolved in DCM $(10 \mathrm{~mL})$. To the solution, $\mathrm{Ph}_{3} \mathrm{PAuCl}(0.013 \mathrm{~g}$, $0.025 \mathrm{mmol})$ and AgOTf $(0.0065 \mathrm{~g}, 0.025 \mathrm{mmol})$ were added and the mixture was stirred vigorously in the dark (the flask was wrapped in $\mathrm{Al}$ foil) for $10 \mathrm{~min}$. The residue was concentrated by rotary evaporation and purified by silica gel column chromatography (hexane).
5-Cyclopropyl-3-fluoro-2-phenylfuran (7b). From $\quad 6 b$ (0.150 g, $0.500 \mathrm{mmol})$. Obtained $7 \mathbf{b}(0.092 \mathrm{~g}, 0.46 \mathrm{mmol}, 92 \%)$ as a yellow oil. Calcd for $\mathrm{C}_{13} \mathrm{H}_{11} \mathrm{FO}$ : $\mathrm{C}, 77.21$; H, 5.48. Found: C, 76.75; H, 6.40. IR ( $v, \mathrm{~cm}^{-1}$, neat) 2924, 1653, 1636, 1559, 1457, 1424, 668. MS (EI, m/z): $202\left(\mathrm{M}^{+}\right)$. NMR $(\delta, \mathrm{ppm}):{ }^{1} \mathrm{H}$ (acetone- $\left.d_{6}\right) 7.64-7.58(\mathrm{~m}, 2 \mathrm{H}), 7.48-7.40(\mathrm{~m}, 2 \mathrm{H}), 7.29-7.23$ $(\mathrm{m}, 1 \mathrm{H}), 6.28(\mathrm{~d}, J=0.8 \mathrm{~Hz}, 1 \mathrm{H}), 2.04-1.96(\mathrm{~m}, 1 \mathrm{H}), 1.02-0.96$ $(\mathrm{m}, 2 \mathrm{H}), 0.91-0.85(\mathrm{~m}, 2 \mathrm{H}) ;{ }^{13} \mathrm{C}$ (acetone- $\left.d_{6}\right) 156.2(\mathrm{~d}, J=9.0$ $\mathrm{Hz}), 150.7$ (d, $J=252.0 \mathrm{~Hz}), 134.9$ (d, $J=20.6 \mathrm{~Hz}), 130.2$ (d, $J=5.0 \mathrm{~Hz}), 129.8,127.6(\mathrm{~d}, J=1.3 \mathrm{~Hz}), 123.7(\mathrm{~d}, J=5.3 \mathrm{~Hz})$, $99.3(\mathrm{~d}, J=20.2 \mathrm{~Hz}), 10.1(\mathrm{~d}, J=1.3 \mathrm{~Hz}), 7.6 ;{ }^{19} \mathrm{~F}\left(\mathrm{CDCl}_{3}\right)$ -163.0 .

3-Fluoro-2-(4-fluorophenyl)-5-(4-methylphenyl)furan (7c). From 6c $(0.184 \mathrm{~g}, 0.500 \mathrm{mmol})$. Obtained 7c $(0.125 \mathrm{~g}$, $0.480 \mathrm{mmol}, 96 \%)$ as a white solid, mp 100-101 ${ }^{\circ} \mathrm{C}$. Calcd for $\mathrm{C}_{17} \mathrm{H}_{12} \mathrm{~F}_{2} \mathrm{O}$ : C, 75.55; H, 4.48. Found: C, 75.50; H, 4.60. IR ( $v$, $\left.\mathrm{cm}^{-1}, \mathrm{KBr}\right) 2921,1635,1507,1403,1234,826,792 . \mathrm{MS}$ (EI, $\mathrm{m} / z): 270\left(\mathrm{M}^{+}\right)$. NMR $(\delta, \mathrm{ppm}):{ }^{1} \mathrm{H}$ (acetone- $\left.d_{6}\right) 7.85-7.78(\mathrm{~m}$, $2 \mathrm{H}), 7.77-7.70(\mathrm{~m}, 2 \mathrm{H}), 7.32-7.25(\mathrm{~m}, 4 \mathrm{H}), 7.02(\mathrm{~d}, J=0.84$ $\mathrm{Hz}, 1 \mathrm{H}), 2.36(\mathrm{~s}, 3 \mathrm{H}) ;{ }^{13} \mathrm{C}$ (acetone- $\left.d_{6}\right) 162.7$ (dd, $J=245.7,2.1$ $\mathrm{Hz}), 151.8(\mathrm{~d}, J=9.8 \mathrm{~Hz}), 151.3(\mathrm{dd}, J=252.0,1.7 \mathrm{~Hz}), 139.4$, $135.5(\mathrm{~d}, J=20.8 \mathrm{~Hz}), 130.5,128.3(\mathrm{~d}, J=2.1 \mathrm{~Hz}), 126.4(\mathrm{dd}, J$ $=5.2,3.0 \mathrm{~Hz}), 126.3(\mathrm{dd}, J=8.1,5.3 \mathrm{~Hz}), 124.7,116.9(\mathrm{~d}, J=$ $22.1 \mathrm{~Hz}), 99.7(\mathrm{~d}, J=20.3 \mathrm{~Hz}), 21.4 ;{ }^{19} \mathrm{~F}\left(\mathrm{CDCl}_{3}\right)-114.8$, -163.0 .

2-(4-Bromophenyl)-3-fluoro-5-(4-methylphenyl)furan (7d). From 6d (0.214 g, $0.500 \mathrm{mmol})$. Obtained 7d $(0.155 \mathrm{~g}$, $0.468 \mathrm{mmol}, 94 \%$ ) as a white solid, mp 110-112 ${ }^{\circ} \mathrm{C}$. HRMS (DART-TOF) Calcd for [M] ${ }^{+} \mathrm{C}_{17} \mathrm{H}_{12} \mathrm{BrFO}$ : 330.0056. Found: 330.0265. IR $\left(v, \mathrm{~cm}^{-1}, \mathrm{KBr}\right) 2923,1636,1499,1395,824,790$. MS (EI, m/z): $331\left(\mathrm{M}^{+}\right) . \operatorname{NMR}(\delta, \mathrm{ppm}):{ }^{1} \mathrm{H}$ (acetone- $\left.d_{6}\right)$ $7.76-7.59(\mathrm{~m}, 6 \mathrm{H}), 7.27(\mathrm{~d}, J=7.9 \mathrm{~Hz}, 2 \mathrm{H}), 6.98(\mathrm{~d}, J=0.7$ $\mathrm{Hz}, 1 \mathrm{H}), 2.35(\mathrm{~s}, 3 \mathrm{H}) ;{ }^{13} \mathrm{C}$ (acetone- $\left.d_{6}\right) 152.3(\mathrm{~d}, J=9.0 \mathrm{~Hz})$, 152.0 (d, $J=253.7 \mathrm{~Hz}), 139.6,135.3$ (d, $J=20.6 \mathrm{~Hz}), 133.0$, 130.5, 128.9 (d, $J=4.9 \mathrm{~Hz}), 128.2(\mathrm{~d}, J=2.1 \mathrm{~Hz}), 125.9$ (d, $J=$ $5.4 \mathrm{~Hz}), 124.8,121.2(\mathrm{~d}, J=2.3 \mathrm{~Hz}), 100.0(\mathrm{~d}, J=20.4 \mathrm{~Hz})$, 21.4; ${ }^{19} \mathrm{~F}\left(\mathrm{CDCl}_{3}\right)-160.8$.

2-(4-Bromophenyl)-5-(4-tert-butylphenyl)-3-fluorofuran (7e). From 6e $(0.235 \mathrm{~g}, 0.500 \mathrm{mmol})$. Obtained 7e $(0.172 \mathrm{~g}$, $0.461 \mathrm{mmol}, 92 \%$ ) as a white solid, mp 72-73 ${ }^{\circ} \mathrm{C}$. Calcd for $\mathrm{C}_{20} \mathrm{H}_{18}$ BrFO: C, 64.36; H, 4.86. Found: C, 64.64; H, 4.95. IR $\left(v, \mathrm{~cm}^{-1}, \mathrm{KBr}\right) 2959,1636,1395,831,820 . \mathrm{MS}(\mathrm{EI}, \mathrm{m} / \mathrm{z}): 373$ $\left(\mathrm{M}^{+}\right) . \operatorname{NMR}(\delta, \mathrm{ppm}):{ }^{1} \mathrm{H}$ (acetone- $\left.d_{6}\right)$ 7.80-7.74 (m, 2H), 7.73-7.64 (m, 4H), 7.54-7.49 (m, 2H), $7.03(\mathrm{~d}, J=0.8 \mathrm{~Hz}, 1 \mathrm{H})$, $1.34(\mathrm{~s}, 9 \mathrm{H}) ;{ }^{13} \mathrm{C}$ (acetone- $\left.d_{6}\right) 152.7,152.2(\mathrm{~d}, J=8.8 \mathrm{~Hz})$, $152.0(\mathrm{~d}, J=253.6 \mathrm{~Hz}), 135.4(\mathrm{~d}, J=20.6 \mathrm{~Hz}), 133.0,128.9$ $(\mathrm{d}, J=5.0 \mathrm{~Hz}), 128.1(\mathrm{~d}, J=2.1 \mathrm{~Hz}), 126.8,125.9(\mathrm{~d}, J=5.4$ $\mathrm{Hz}), 124.7,121.2$ (d, $J=2.3 \mathrm{~Hz}), 100.0$ (d, $J=20.1 \mathrm{~Hz}), 35.4$, 31.6; ${ }^{19} \mathrm{~F}\left(\mathrm{CDCl}_{3}\right)-160.7$.

3-Fluoro-5-(4-methylphenyl)-2-[4-(trifluoromethyl)phenyl] furan (7f). From 6 f $(0.208 \mathrm{~g}, 0.500 \mathrm{mmol})$. Obtained $7 \mathbf{f}$ $(0.142 \mathrm{~g}, 0.444 \mathrm{mmol}, 89 \%)$ as a white solid, mp $132-133{ }^{\circ} \mathrm{C}$. Calcd for $\mathrm{C}_{18} \mathrm{H}_{12} \mathrm{~F}_{4} \mathrm{O}$ : C, 67.50; H, 3.78. Found: C, 67.22; $\mathrm{H}$, 3.67. IR ( $\left.v, \mathrm{~cm}^{-1}, \mathrm{KBr}\right) 2926,1634,1410,1339,1165,1108$, 1072, 840, 792. MS (EI, $m / z): 320\left(\mathrm{M}^{+}\right) . \operatorname{NMR}(\delta, \mathrm{ppm}):{ }^{1} \mathrm{H}$ (acetone- $\left.d_{6}\right) 7.82(\mathrm{~d}, J=8.2 \mathrm{~Hz}, 2 \mathrm{H}), 7.97(\mathrm{~d}, J=8.2 \mathrm{~Hz}, 2 \mathrm{H})$, 
7.80-7.74 (m, 2H), 7.36-7.28 (m, 2H), $7.08(\mathrm{~d}, J=0.7 \mathrm{~Hz}, 1 \mathrm{H})$, $2.38(\mathrm{~s}, 3 \mathrm{H}) ;{ }^{13} \mathrm{C}$ (acetone- $\left.d_{6}\right) 153.2(\mathrm{~d}, J=8.8 \mathrm{~Hz}), 153.1(\mathrm{~d}$, $J=255.6 \mathrm{~Hz}), 139.9,134.9(\mathrm{~d}, J=20.4 \mathrm{~Hz}), 133.3(\mathrm{~d}, J=3.8$ $\mathrm{Hz}), 130.6,128.9(\mathrm{qd}, J=33.3,1.9 \mathrm{~Hz}), 128.0(\mathrm{~d}, J=2.2 \mathrm{~Hz})$, 126.9 (q, $J=3.9 \mathrm{~Hz}), 125.4$ (q, $J=271.2 \mathrm{~Hz}), 125.0,124.4$ (d, $J=5.5 \mathrm{~Hz}), 99.9(\mathrm{~d}, J=20.1 \mathrm{~Hz}), 21.4 ;{ }^{19} \mathrm{~F}\left(\mathrm{CDCl}_{3}\right)-63.0$ $(3 \mathrm{~F}),-158.9(1 \mathrm{~F})$.

2-Ethyl-3-fluoro-5-phenylfuran (7g). From $\mathbf{6 g} \quad(0.143 \quad \mathrm{~g}$, $0.500 \mathrm{mmol})$. Obtained $7 \mathrm{~g}(0.049 \mathrm{~g}, 0.26 \mathrm{mmol}, 52 \%)$ as a colorless oil. NMR (acetone- $\left.d_{6}, \delta, \mathrm{ppm}\right):{ }^{1} \mathrm{H} 7.71-7.64(\mathrm{~m}, 2 \mathrm{H})$, $7.45-7.37(\mathrm{~m}, 2 \mathrm{H}), 7.33-7.26(\mathrm{~m}, 1 \mathrm{H}), 6.83(\mathrm{~d}, J=1.2 \mathrm{~Hz}, 1 \mathrm{H})$, $2.73(\mathrm{qd}, J=7.6,1.8 \mathrm{~Hz}, 2 \mathrm{H}) ; 1.27(\mathrm{t}, J=7.6 \mathrm{~Hz}, 3 \mathrm{H}) ;{ }^{13} \mathrm{C}$ $150.3(\mathrm{~d}, J=9.2 \mathrm{~Hz}), 150.2(\mathrm{~d}, J=243.4 \mathrm{~Hz}), 140.0(\mathrm{~d}, J=$ $25.9 \mathrm{~Hz}), 131.5(\mathrm{~d}, J=2.1 \mathrm{~Hz}), 129.7,128.6,124.1,99.0(\mathrm{~d}, J=$ $20.6 \mathrm{~Hz}), 18.9$ (d, $J=3.1 \mathrm{~Hz}), 12.4$ (d, $J=1.7 \mathrm{~Hz})$.

\section{3-Bromo-4-fluorofurans (8) and 3-fluoro-4-iodofurans (9): general procedure}

The flask containing crude 2 (obtained from $\mathbf{6}$ as described above) was charged with $N$-halosuccinimide (NIS $0.135 \mathrm{~g}$, $0.600 \mathrm{mmol}$ or NBS, $0.107 \mathrm{~g}, 0.600 \mathrm{mmol}$ ) and anhydrous DCM $(7.0 \mathrm{~mL})$. The mixture was stirred for a few minutes to become homogeneous, then anhydrous ground $\mathrm{ZnBr}_{2}(0.0225 \mathrm{~g}$, $0.100 \mathrm{mmol}$ ) was added followed immediately by $\mathrm{AuCl}$ $(0.0058 \mathrm{~g}, 0.025 \mathrm{mmol})$ in anhydrous DCM $(3.0 \mathrm{~mL})$. The mixture was stirred vigorously at ambient temperature for $10 \mathrm{~min}$. The reaction was quenched by adding saturated sodium thiosulfate aqueous solution $(10 \mathrm{~mL})$ and stirred for few minutes. DCM $(60 \mathrm{~mL})$ was added. The organic layer was separated, dried over $\mathrm{MgSO}_{4}$, filtered, and concentrated under reduced pressure. The product was purified by silica gel column chromatography (hexane).

3-Bromo-4-fluoro-2-(4-methylphenyl)-5-phenylfuran (8a). From 6a $(0.175 \mathrm{~g}, 0.500 \mathrm{mmol})$. Obtained 8a (0.103 g, $0.311 \mathrm{mmol}, 62 \%$ ) as a white solid, $\mathrm{mp} 75-76{ }^{\circ} \mathrm{C}$. Calcd for $\mathrm{C}_{17} \mathrm{H}_{12} \mathrm{BrFO}$ : C, 61.65; H, 3.65. Found: C, 61.95; H, 3.82. IR $\left(v, \mathrm{~cm}^{-1}, \mathrm{KBr}\right) 2924,1636,1499,943,817,760,687 . \mathrm{MS}$ (EI, $\mathrm{m} / z): 330\left(100 \%, \mathrm{M}^{+}\right)$. NMR $(\delta, \mathrm{ppm}):{ }^{1} \mathrm{H}$ (acetone- $\left.d_{6}\right)$ 8.00-7.94 (m, 2H), 7.82-7.75 (m, 2H), 7.57-7.49 (m, 2H), $7.42-7.33(\mathrm{~m}, 3 \mathrm{H}), 2.39(\mathrm{~s}, 3 \mathrm{H}) ;{ }^{13} \mathrm{C}$ (acetone- $\left.d_{6}\right) 148.8(\mathrm{~d}, J=$ $252.4 \mathrm{~Hz}), 147.1(\mathrm{~d}, J=4.4 \mathrm{~Hz}), 140.2,136.1(\mathrm{~d}, J=19.0 \mathrm{~Hz})$, 130.4, 130.1, 129.0 (d, $J=1.4 \mathrm{~Hz}), 128.8$ (d, $J=5.0 \mathrm{~Hz}), 127.4$, 126.2, $124.6(\mathrm{~d}, J=5.0 \mathrm{~Hz}), 89.6(\mathrm{~d}, J=21.5 \mathrm{~Hz}), 21.4 ;{ }^{19} \mathrm{~F}$ $\left(\mathrm{CDCl}_{3}\right)-162.2$.

3-Bromo-2-cyclopropyl-4-fluoro-5-phenylfuran (8b). From $6 b$ $(0.150 \mathrm{~g}, 0.500 \mathrm{mmol})$. Obtained $\mathbf{8 b}(0.110 \mathrm{~g}, 0.391 \mathrm{mmol}$, $78 \%)$ as a white soft solid. IR $\left(v, \mathrm{~cm}^{-1}\right.$, neat) $2925,1638,1497$, 1428, 1002, 759. MS (EI, $m / z): 280\left(100 \%, \mathrm{M}^{+}\right)$. HRMS (DART-TOF) Calcd for $[\mathrm{M}+\mathrm{H}]^{+} \mathrm{C}_{13} \mathrm{H}_{11} \mathrm{BrFO} 280.9977$. Found 280.9978. $\mathrm{NMR}(\delta, \mathrm{ppm}):{ }^{1} \mathrm{H}\left(\mathrm{CDCl}_{3}\right) 7.62-7.55(\mathrm{~m}, 2 \mathrm{H})$, 7.43-7.36 (m, 2H), 7.26-7.22 (m, 1H), 2.04-1.94 (m, 1H), $1.09-0.98(\mathrm{~m}, 4 \mathrm{H}) ;{ }^{13} \mathrm{C}$ (acetone- $\left.d_{6}\right) 151.8(\mathrm{~d}, J=4.5 \mathrm{~Hz})$, $148.0(\mathrm{~d}, J=252.5 \mathrm{~Hz}), 134.8(\mathrm{~d}, J=19.7 \mathrm{~Hz}), 129.9,129.2$ (d, $J=5.1 \mathrm{~Hz}), 128.4(\mathrm{~d}, J=1.4 \mathrm{~Hz}), 124.0(\mathrm{~d}, J=5.1 \mathrm{~Hz}), 89.9$ $(\mathrm{d}, J=21.3 \mathrm{~Hz}), 9.0,7.3 ;{ }^{19} \mathrm{~F}\left(\mathrm{CDCl}_{3}\right)-163.8$.
3-Bromo-4-fluoro-5-(4-fluorophenyl)-2-(4-methylphenyl)furan (8c). From 6c $(0.183 \mathrm{~g}, 0.500 \mathrm{mmol})$. Obtained 8c $(0.125 \mathrm{~g}$, $0.358 \mathrm{mmol}, 72 \%$ ) as a white solid, $\mathrm{mp} 103-105{ }^{\circ} \mathrm{C}$. Calcd for $\mathrm{C}_{17} \mathrm{H}_{11} \mathrm{BrF}_{2} \mathrm{O}$ : C, 58.48; H, 3.18. Found: C, 58.32; H, 3.50. IR $\left(v, \mathrm{~cm}^{-1}, \mathrm{KBr}\right) 2922,1508,1406,1233,945,828,812$. MS (EI, $m / z): 348\left(100 \%, \mathrm{M}^{+}\right)$. NMR $(\delta, \mathrm{ppm}):{ }^{1} \mathrm{H}$ (acetone- $\left.d_{6}\right) 7.96(\mathrm{~d}$, $J=8.3 \mathrm{~Hz}, 2 \mathrm{H}), 7.87-7.81(\mathrm{~m}, 2 \mathrm{H}), 7.36(\mathrm{~d}, J=8.2 \mathrm{~Hz}, 2 \mathrm{H})$, $7.35-7.28(\mathrm{~m}, 2 \mathrm{H}), 2.39(\mathrm{~s}, 3 \mathrm{H}) ;{ }^{13} \mathrm{C}$ (acetone- $\left.d_{6}\right) 163.2(\mathrm{dd}, J=$ 247.2, $2.2 \mathrm{~Hz}), 148.5$ (dd, $J=252.0,2.2 \mathrm{~Hz}), 147.2(\mathrm{~d}, J=3.8$ $\mathrm{Hz}), 140.2,135.4$ (d, $J=19.3 \mathrm{~Hz}), 130.5,127.3$ (d, $J=1.5 \mathrm{~Hz})$, $126.8(\mathrm{dd}, J=8.5,5.0 \mathrm{~Hz}), 126.2,125.4(\mathrm{dd}, J=5.1,3.1 \mathrm{~Hz})$, $117.1(\mathrm{~d}, J=22.4 \mathrm{~Hz}), 89.6(\mathrm{~d}, J=21.5 \mathrm{~Hz}), 21.4 ;{ }^{19} \mathrm{~F}\left(\mathrm{CDCl}_{3}\right)$ $-163.0,-113.5$.

3-Bromo-5-(4-bromophenyl)-4-fluoro-2-(4-methylphenyl)furan (8d). From 6d (0.214 g, $0.500 \mathrm{mmol})$. Obtained 8d (0.139 g, $0.339 \mathrm{mmol}, 68 \%$ ) as a white solid, $\mathrm{mp} 101-103{ }^{\circ} \mathrm{C}$. Calcd for $\mathrm{C}_{17} \mathrm{H}_{11} \mathrm{Br}_{2} \mathrm{FO}$ : C, 49.79; H, 2.70. Found: C, 50.05; H, 2.84. IR $\left(v, \mathrm{~cm}^{-1}, \mathrm{KBr}\right) 2923,1636,1488,1397,944,821$. MS (EI, $\left.\mathrm{m} / z\right)$ : $410\left(100 \%, \mathrm{M}^{+}\right)$. NMR $(\delta, \mathrm{ppm}):{ }^{1} \mathrm{H}$ (acetone- $\left.d_{6}\right) 8.00-7.94(\mathrm{~m}$, $2 \mathrm{H}), 7.76-7.69(\mathrm{~m}, 4 \mathrm{H}), 7.39-7.34(\mathrm{~m}, 2 \mathrm{H}), 2.40(\mathrm{~s}, 3 \mathrm{H}) ;{ }^{13} \mathrm{C}$ (acetone- $\left.d_{6}\right) 149.2(\mathrm{~d}, J=253.3 \mathrm{~Hz}), 147.6(\mathrm{~d}, J=4.3 \mathrm{~Hz})$, $140.4,135.2$ (d, $J=19.2 \mathrm{~Hz}), 133.2,130.5,127.9$ (d, $J=5.1$ $\mathrm{Hz}), 127.2$ (d, $J=1.4 \mathrm{~Hz}), 126.3$ (d, $J=4.9 \mathrm{~Hz}), 126.3,122.3$ $(\mathrm{d}, J=2.2 \mathrm{~Hz}), 89.7(\mathrm{~d}, J=21.6 \mathrm{~Hz}), 21.5 ;{ }^{19} \mathrm{~F}\left(\mathrm{CDCl}_{3}\right)$ -160.8 .

3-Bromo-5-(4-bromophenyl)-2-(4-tert-butylphenyl)-4-fluorofuran (8e). From 6e $(0.235 \mathrm{~g}, 0.500 \mathrm{mmol})$. Obtained 8e (0.148 $\mathrm{g}, 0.327 \mathrm{mmol}, 65 \%)$ as a white solid, mp $122-123{ }^{\circ} \mathrm{C}$. Calcd for $\mathrm{C}_{20} \mathrm{H}_{17} \mathrm{Br}_{2} \mathrm{FO}$ : C, 53.13; H, 3.79. Found: C, 53.68; $\mathrm{H}$, 3.85. IR $\left(v, \mathrm{~cm}^{-1}, \mathrm{KBr}\right) 2959,1653,1636,832,817,668$. MS $(\mathrm{EI}, \mathrm{m} / \mathrm{z}): 452\left(100 \%, \mathrm{M}^{+}\right) . \mathrm{NMR}(\delta, \mathrm{ppm}):{ }^{1} \mathrm{H}$ (acetone- $\left.d_{6}\right)$ 8.04-7.97 (m, 2H), 7.75-7.68 (m, 4H), 7.63-7.56 (m, 2H), 1.38 $(\mathrm{s}, 9 \mathrm{H}) ;{ }^{13} \mathrm{C}$ (acetone- $\left.d_{6}\right) 153.4,149.2(\mathrm{~d}, J=253.4 \mathrm{~Hz}), 147.6$ $(\mathrm{d}, J=4.3 \mathrm{~Hz}), 135.2(\mathrm{~d}, J=19.1 \mathrm{~Hz}), 133.2,127.9(\mathrm{~d}, J=5.1$ $\mathrm{Hz}), 127.2,126.7,126.3$ (d, $J=5.1 \mathrm{~Hz}), 126.2,122.2$ (d, $J=2.1$ $\mathrm{Hz}), 89.8(\mathrm{~d}, J=21.4 \mathrm{~Hz}), 35.5,31.5 ;{ }^{19} \mathrm{~F}\left(\mathrm{CDCl}_{3}\right)-160.8$.

2-Cyclopropyl-4-fluoro-3-iodo-5-phenylfuran (9b). From $6 \mathrm{~b}$ $(0.150 \mathrm{~g}, 0.500 \mathrm{mmol})$. Obtained 9b $(0.115 \mathrm{~g}, 0.350 \mathrm{mmol}$, $70 \%$ ) as a white solid, mp $61-62{ }^{\circ} \mathrm{C}$. Calcd for $\mathrm{C}_{13} \mathrm{H}_{10} \mathrm{FIO}: \mathrm{C}$, 47.59; H, 3.07. Found: C, 47.55; H, 3.25. IR ( $\left.v, \mathrm{~cm}^{-1}, \mathrm{KBr}\right)$ 3010, 1636, 1494, 1417, 997, 760. MS (EI, $m / z): 328(100 \%$, $\left.\mathrm{M}^{+}\right)$. NMR $(\delta, \mathrm{ppm}):{ }^{1} \mathrm{H}\left(\mathrm{CDCl}_{3}\right)$ 7.62-7.54 (m, 2H), 7.43-7.36 $(\mathrm{m}, 2 \mathrm{H}), 7.26-7.21(\mathrm{~m}, 1 \mathrm{H}), 2.02-1.94(\mathrm{~m}, 1 \mathrm{H}), 1.09-0.97(\mathrm{~m}$, $4 \mathrm{H}) ;{ }^{13} \mathrm{C}$ (acetone- $\left.d_{6}\right) 154.8(\mathrm{~d}, J=6.1 \mathrm{~Hz}), 150.8(\mathrm{~d}, J=251.2$ Hz), 134.9 (d, $J=21.0 \mathrm{~Hz}), 129.8,129.2$ (d, $J=5.2 \mathrm{~Hz}), 128.2$, $123.9(\mathrm{~d}, J=5.1 \mathrm{~Hz}), 57.4(\mathrm{~d}, J=24.8 \mathrm{~Hz}), 10.3,7.7 ;{ }^{19} \mathrm{~F}$ $\left(\mathrm{CDCl}_{3}\right)-159.0$.

3-Fluoro-2-(4-fluorophenyl)-4-iodo-5-(4-methylphenyl)furan (9c). From 6c $(0.183 \mathrm{~g}, 0.500 \mathrm{mmol})$. Obtained 9c $(0.135 \mathrm{~g}$, $0.341 \mathrm{mmol}, 68 \%$ ) as a white solid, mp 98-99 ${ }^{\circ} \mathrm{C}$. Calcd for $\mathrm{C}_{17} \mathrm{H}_{11} \mathrm{~F}_{2} \mathrm{IO}: \mathrm{C}, 51.54$; H, 2.80. Found: C, 51.94; H, 3.21. IR ( $v$, $\left.\mathrm{cm}^{-1}, \mathrm{KBr}\right) 2919,1701,1653,1508,837,817 . \mathrm{MS}$ (EI, $\left.\mathrm{m} / z\right)$ : $396\left(100 \%, \mathrm{M}^{+}\right)$. NMR $(\delta, \mathrm{ppm}):{ }^{1} \mathrm{H}$ (acetone- $\left.d_{6}\right) 8.03-7.97(\mathrm{~m}$, 2H), 7.85-7.78 (m, 2H), 7.39-7.26 (m, 4H), $2.40(\mathrm{~s}, 3 \mathrm{H}) ; 13 \mathrm{C}$ (acetone- $\left.d_{6}\right) 163.1(\mathrm{dd}, J=246.6,2.2 \mathrm{~Hz}), 151.5(\mathrm{dd}, J=250.1$, 
$2.2 \mathrm{~Hz}), 149.7(\mathrm{~d}, J=6.0 \mathrm{~Hz}), 140.2,135.5(\mathrm{~d}, J=21.2 \mathrm{~Hz})$, $130.3,128.0$ (d, $J=1.3 \mathrm{~Hz}), 126.9,126.7$ (dd, $J=8.2,5.1 \mathrm{~Hz})$, $125.5(\mathrm{dd}, J=5.1,3.5 \mathrm{~Hz}), 117.1(\mathrm{~d}, J=22.2 \mathrm{~Hz}), 56.9(\mathrm{~d}, J=$ $25.1 \mathrm{~Hz}), 21.4 ;{ }^{19} \mathrm{~F}\left(\mathrm{CDCl}_{3}\right)-157.6,-113.7$.

2-(4-Bromophenyl)-3-fluoro-4-iodo-5-(4-methylphenyl)furan (9d). From 6d (0.214 g, $0.500 \mathrm{mmol})$. Obtained 9d $(0.158 \mathrm{~g}$, $0.346 \mathrm{mmol}, 69 \%$ ) as a white solid, mp $104-106{ }^{\circ} \mathrm{C}$. Calcd for $\mathrm{C}_{17} \mathrm{H}_{11}$ BrFIO: $\mathrm{C}$, 44.67; H, 2.43. Found: C, 45.12; H, 2.49. IR $\left(v, \mathrm{~cm}^{-1}, \mathrm{KBr}\right) 2920,1700,1653,1559,940,824$. MS (EI, $\left.m / z\right)$ : $456\left(100 \%, \mathrm{M}^{+}\right)$. NMR $(\delta, \mathrm{ppm}):{ }^{1} \mathrm{H}$ (acetone- $\left.d_{6}\right) 8.04-7.99(\mathrm{~m}$, $2 \mathrm{H}), 7.75-7.68(\mathrm{~m}, 4 \mathrm{H}), 7.40-7.34(\mathrm{~m}, 2 \mathrm{H}), 2.40(\mathrm{~s}, 3 \mathrm{H}) ;{ }^{13} \mathrm{C}$ (acetone- $\left.d_{6}\right) 152.2(\mathrm{~d}, J=251.5 \mathrm{~Hz}), 150.2(\mathrm{~d}, J=5.9 \mathrm{~Hz})$, $140.4,135.3$ (d, $J=20.8 \mathrm{~Hz}), 133.2,130.3,128.0(\mathrm{~d}, J=5.4$ Hz), 127.9 (d, $J=1.4 \mathrm{~Hz}), 126.9,126.3$ (d, $J=5.1 \mathrm{~Hz}), 122.0$ $(\mathrm{d}, J=2.4 \mathrm{~Hz}), 57.0(\mathrm{~d}, J=24.9 \mathrm{~Hz}), 21.4 ;{ }^{19} \mathrm{~F}\left(\mathrm{CDCl}_{3}\right)$ -155.3 .

2-(4-Bromophenyl)-5-(4-tert-butylphenyl)-3-fluoro-4-iodofuran (9e). From 6e $(0.235 \mathrm{~g}, 0.500 \mathrm{mmol})$. Obtained 9e $(0.156 \mathrm{~g}$, $0.313 \mathrm{mmol}, 63 \%$ ) as a white solid, $\mathrm{mp} 143-144{ }^{\circ} \mathrm{C}$. Calcd for $\mathrm{C}_{20} \mathrm{H}_{17}$ BrFIO: C, 48.12; H, 3.43. Found: C, 48.22; H, 3.33. IR $\left(v, \mathrm{~cm}^{-1}, \mathrm{KBr}\right) 2958,1653,1559,1395,940,832,816,668 . \mathrm{MS}$ $(\mathrm{EI}, \mathrm{m} / z): 498\left(100 \%, \mathrm{M}^{+}\right) . \mathrm{NMR}(\delta, \mathrm{ppm}):{ }^{1} \mathrm{H}$ (acetone- $\left.d_{6}\right)$ 8.10-8.05 (m, 2H), 7.77-7.69 (m, 4H), 7.64-7.59 (m, 2H), 1.38 $(\mathrm{s}, 9 \mathrm{H}) ;{ }^{13} \mathrm{C}$ (acetone- $\left.d_{6}\right) 153.4,152.2(\mathrm{~d}, J=251.7 \mathrm{~Hz}), 150.2$ $(\mathrm{d}, J=5.9 \mathrm{~Hz}), 135.4(\mathrm{~d}, J=21.1 \mathrm{~Hz}), 133.2,128.0(\mathrm{~d}, J=5.1$ Hz), 127.9 (d, $J=1.5 \mathrm{~Hz}), 126.8,126.6,126.3(\mathrm{~d}, J=5.1 \mathrm{~Hz})$, $122.0(\mathrm{~d}, J=2.2 \mathrm{~Hz}), 57.1(\mathrm{~d}, J=24.9 \mathrm{~Hz}), 35.5,31.5 ;{ }^{19} \mathrm{~F}$ $\left(\mathrm{CDCl}_{3}\right)-155.3$.

3-Fluoro-4-iodo-5-(4-methylphenyl)-2-[4-(trifluoromethyl) phenyl]furan (9f). From 6 f $(0.208 \mathrm{~g}, 0.500 \mathrm{mmol})$. Obtained $9 f$ (0.085 g, $0.19 \mathrm{mmol}, 38 \%)$ as a white solid, mp 79-81 ${ }^{\circ} \mathrm{C}$. IR $\left(v, \mathrm{~cm}^{-1}, \mathrm{KBr}\right) 2924,2853,1616,1407,1326,1164,1107$, $1070,839,816$. MS (EI, $m / z): 446\left(100 \%, \mathrm{M}^{+}\right)$. HRMS (DART-TOF) Calcd for $\mathrm{M}^{+} \mathrm{C}_{18} \mathrm{H}_{11} \mathrm{~F}_{4} \mathrm{IO}$ : 445.9791. Found: 445.9772. NMR $(\delta, \mathrm{ppm}):{ }^{1} \mathrm{H}$ (acetone- $\left.d_{6}\right)$ 8.06-8.00 (m, 2H), $7.97(\mathrm{~d}, J=8.2 \mathrm{~Hz}, 2 \mathrm{H}), 7.85$ (d, $J=8.3 \mathrm{~Hz}, 2 \mathrm{H}), 7.37$ (d, $J=$ $8.0 \mathrm{~Hz}, 2 \mathrm{H}), 2.40(\mathrm{~s}, 3 \mathrm{H}) ;{ }^{13} \mathrm{C}$ (acetone- $\left.d_{6}\right) 153.2(\mathrm{~d}, J=253.5$ $\mathrm{Hz}), 150.9$ (d, $J=5.9 \mathrm{~Hz}), 140.7,134.9$ (d, $J=20.7 \mathrm{~Hz}), 132.3$ $(\mathrm{d}, J=5.3 \mathrm{~Hz}), 130.3,129.5(\mathrm{q}, J=32.4 \mathrm{~Hz}), 127.7$ (d, $J=1.3$ $\mathrm{Hz}), 127.0,127.0$ (q, $J=3.9 \mathrm{~Hz}), 125.3$ (q, $J=271.3 \mathrm{~Hz}), 124.8$ $(\mathrm{d}, J=5.5 \mathrm{~Hz}), 57.1(\mathrm{~d}, J=25.0 \mathrm{~Hz}), 21.4 ;{ }^{19} \mathrm{~F}\left(\mathrm{CDCl}_{3}\right)$ $-153.4,-63.1$.

\section{3-Fluoro-5-(4-methylphenyl)-2-phenyl-4-(phenylethynyl)furan (10)}

A $10 \mathrm{~mL}$ microwave reaction vial was charged with the iodofuran 9a $(0.095 \mathrm{~g}, 0.25 \mathrm{mmol}), \mathrm{PdCl}_{2}\left(\mathrm{PPh}_{3}\right)_{2}(0.018 \mathrm{~g}$, $0.025 \mathrm{mmol})$, and $\mathrm{CuI}(4.8 \mathrm{mg}, 0.025 \mathrm{mmol})$. The reaction vial was sealed, then evacuated-backfilled with nitrogen (Schlenk line, three times). Under nitrogen protection, degassed toluene $(5 \mathrm{~mL})$ and $\mathrm{Et}_{3} \mathrm{~N}(0.10 \mathrm{~mL}, 0.75 \mathrm{mmol})$ were injected into the vial. Then phenylacetylene $(80 \mu \mathrm{L}, 0.73 \mathrm{mmol})$ was injected to the reaction. The reaction vial was submitted to microwave irradiation with stirring $\left(80^{\circ} \mathrm{C}, 1 \mathrm{~h}\right)$. After 9a had been consumed, as judged by TLC analysis of an aliquot of reaction solution, the reaction mixture was transferred to a flask with the aid of ethyl ether $(50 \mathrm{~mL})$ and concentrated under vacuum. The residue was purified by silica gel flash chromatography (hexanes) to give $\mathbf{1 0}$ as a white solid (0.080 g, $0.23 \mathrm{mmol}, 92 \%)$, mp $132-133{ }^{\circ} \mathrm{C}$. IR $\left(v, \mathrm{~cm}^{-1}, \mathrm{KBr}\right) 3032,2919,2218,1636$, $819,755,668$. MS (EI, $m / z): 352\left(100 \%, \mathrm{M}^{+}\right)$. HRMS (DART-TOF) Calcd for $[\mathrm{M}+\mathrm{H}]^{+} \mathrm{C}_{25} \mathrm{H}_{18} \mathrm{FO}$ : 353.1342. Found: 353.1330. NMR $\left(\mathrm{CDCl}_{3}, \delta, \mathrm{ppm}\right):{ }^{1} \mathrm{H} 8.07(\mathrm{~d}, J=8.3 \mathrm{~Hz}, 2 \mathrm{H})$, 7.82-7.77 (m, 2H), 7.64-7.57 (m, 2H), 7.49-7.38 (m, 5H), $7.34-7.28(\mathrm{~m}, 3 \mathrm{H}), 2.42(\mathrm{~s}, 3 \mathrm{H}) ;{ }^{13} \mathrm{C} 151.6(\mathrm{~d}, J=4.8 \mathrm{~Hz})$, 149.4 (d, $J=258.9 \mathrm{~Hz}), 139.1,135.1$ (d, $J=18.6 \mathrm{~Hz}), 131.8$, $129.6,129.0,128.9,128.7,128.6,127.7,127.6(\mathrm{~d}, J=1.5 \mathrm{~Hz})$, 125.0, 123.9 (d, $J=5.1 \mathrm{~Hz}), 123.2,97.6$ (d, $J=17.4 \mathrm{~Hz}), 96.9$, $78.3(\mathrm{~d}, J=2.5 \mathrm{~Hz}), 21.7 ;{ }^{19} \mathrm{~F}-161.7$.

\section{3-Fluoro-5-(4-methylphenyl)-2-phenyl-4-(thiophen-3-yl)furan (11)}

A $10 \mathrm{~mL}$ microwave reaction vial was charged with the iodofuran 9a $(0.095 \mathrm{~g}, 0.25 \mathrm{mmol}), 3$-thiophene-3-boronic acid (0.064 g, $0.50 \mathrm{mmol}), \mathrm{Pd}\left(\mathrm{PPh}_{3}\right)_{4}(0.029 \mathrm{~g}, 0.025 \mathrm{mmol})$, and $\mathrm{Na}_{2} \mathrm{CO}_{3}(0.053 \mathrm{~g}, 0.50 \mathrm{mmol})$. The reaction vial was sealed, evacuated and backfilled with nitrogen (Schlenk line, three times). Under nitrogen protection, degassed toluene $(5 \mathrm{~mL})$, EtOH $(0.5 \mathrm{~mL})$ and $\mathrm{H}_{2} \mathrm{O}(0.2 \mathrm{~mL})$ were injected into the vial successively. The reaction vial was submitted to microwave irradiation with stirring $\left(110{ }^{\circ} \mathrm{C}, 2 \mathrm{~h}\right)$, and monitored by TLC analysis of an aliquot of the reaction solution. The reaction mixture was transferred to a separatory funnel with the aid of ether $(60 \mathrm{~mL})$ and washed with brine $(10 \mathrm{~mL})$. The organic layer was dried over $\mathrm{MgSO}_{4}$, filtered and concentrated under vacuum. The residue was purified by silica gel column chromatography (hexane) to give $\mathbf{1 1}$ as a white solid $(0.077 \mathrm{~g}, 0.23 \mathrm{mmol}, 92 \%)$, mp 79-81 ${ }^{\circ} \mathrm{C}$. Calcd for $\mathrm{C}_{21} \mathrm{H}_{15}$ FOS: C, 75.42; H, 4.52. Found: C, 75.89; H, 4.88. IR ( $\left.v, \mathrm{~cm}^{-1}, \mathrm{KBr}\right) 2924,2854,1495,1442$, 820, 759. MS (EI, m/z): $334\left(100 \%, \mathrm{M}^{+}\right)$. NMR $\left(\mathrm{CDCl}_{3}, \delta\right.$, ppm): ${ }^{1} \mathrm{H} 7.83-7.77(\mathrm{~m}, 2 \mathrm{H}), 7.56-7.50(\mathrm{~m}, 2 \mathrm{H}), 7.49-7.42(\mathrm{~m}$, $3 \mathrm{H}), 7.39(\mathrm{dd}, J=5.0,3.0 \mathrm{~Hz}, 1 \mathrm{H}), 7.33-7.28(\mathrm{~m}, 1 \mathrm{H})$, $7.21-7.15(\mathrm{~m}, 3 \mathrm{H}), 2.39(\mathrm{~s}, 3 \mathrm{H}) ;{ }^{13} \mathrm{C} 148.8(\mathrm{~d}, J=255.9 \mathrm{~Hz})$, $146.4(\mathrm{~d}, J=6.0 \mathrm{~Hz}), 138.6,135.4(\mathrm{~d}, J=19.6 \mathrm{~Hz}), 129.6$ (d, $J=2.8 \mathrm{~Hz}), 129.5(2 \mathrm{C}), 129.2$ (d, $J=5.0 \mathrm{~Hz}), 129.0$ (2C), 128.2, 127.3, 126.4 (2C), 125.9, 124.2 (d, $J=2.1 \mathrm{~Hz}), 123.8$ (d, $J=5.2 \mathrm{~Hz}, 2 \mathrm{C}), 110.5(\mathrm{~d}, J=16.1 \mathrm{~Hz}), 21.6 ;{ }^{66}{ }^{19} \mathrm{~F}-164.0$.

\section{2-[4-Fluoro-2-(4-methylphenyl)-5-phenylfuran-3-yl]pyridine (12)}

A $10 \mathrm{~mL}$ microwave reaction vial was charged with the iodofuran 9a (0.095 g, $0.25 \mathrm{mmol})$, lithium (pyridin-2-yl)triisoproxyborate $(0.110 \mathrm{~g}, \quad 0.400 \mathrm{mmol}), \quad \mathrm{Pd}\left(\mathrm{PPh}_{3}\right)_{4} \quad(0.029 \mathrm{~g}$, $0.025 \mathrm{mmol}), \mathrm{CuCl}(0.0025 \mathrm{~g}, 0.025 \mathrm{mmol}), \mathrm{Cs}_{2} \mathrm{CO}_{3}(0.098 \mathrm{~g}$, $0.30 \mathrm{mmol})$, and $\mathrm{ZnCl}_{2}(0.034 \mathrm{~g}, 0.25 \mathrm{mmol}$, loaded in glovebox). The reaction vial was sealed, evacuated and backfilled with nitrogen (Schlenk line, three times). Under nitrogen protection, anhydrous degassed DMF ( $2 \mathrm{~mL})$ was injected into the vial. The reaction vial was submitted to microwave irradiation with stirring $\left(110{ }^{\circ} \mathrm{C}, 2 \mathrm{~h}\right)$, and monitored by TLC analysis of an aliquot of reaction solution. After completion, the reaction mixture was transferred to a flask with the aid of ethyl ether $(60 \mathrm{~mL})$ and washed with brine $(10 \mathrm{~mL})$. The organic layer was separated, 
dried over $\mathrm{MgSO}_{4}$, filtered and concentrated under vacuum. The residue was purified by silica gel flash chromatography (hexane/ ethyl acetate $30: 1)$ to give $\mathbf{1 2}$ as a white solid $(0.070 \mathrm{~g}$, $0.22 \mathrm{mmol}, 85 \%$ ), mp $80-82{ }^{\circ} \mathrm{C}$. Calcd for $\mathrm{C}_{22} \mathrm{H}_{16} \mathrm{FNO}$ : C, 80.23; H, 4.90. Found: C, 80.12; H, 5.37. IR $\left(v, \mathrm{~cm}^{-1}, \mathrm{KBr}\right)$ 2920, 1640, 1592, 1416, 816, 763. MS (EI, $m / z): 329(100 \%$, $\left.\mathrm{M}^{+}\right)$. NMR $\left(\mathrm{CDCl}_{3}, \delta, \mathrm{ppm}\right):{ }^{1} \mathrm{H} 8.75(\mathrm{ddd}, J=4.9,1.8,0.9 \mathrm{~Hz}$, $1 \mathrm{H}$ ), 7.85-7.80 (m, 2H), 7.75 (pseudo td $J=7.7,1.8 \mathrm{~Hz}, 2 \mathrm{H}$ ), 7.58-7.53 (m, 2H), 7.52-7.43 (m, 3H), 7.32-7.27 (m, 2H), 7.15 $(\mathrm{d}, J=8.0 \mathrm{~Hz}, 2 \mathrm{H}), 2.37(\mathrm{~s}, 3 \mathrm{H}) ;{ }^{13} \mathrm{C} 150.4(\mathrm{~d}, J=3.5 \mathrm{~Hz})$, 150.2, 148.7 (d, $J=257.0 \mathrm{~Hz}), 147.9(\mathrm{~d}, J=5.7 \mathrm{~Hz}), 138.8$, $136.7,135.7(\mathrm{~d}, J=19.4 \mathrm{~Hz}), 129.3,129.1(\mathrm{~d}, J=4.9 \mathrm{~Hz})$, $129.0,127.8$ (d, $J=1.3 \mathrm{~Hz}), 127.4(\mathrm{~d}, J=1.0 \mathrm{~Hz}), 126.6,125.0$ $(\mathrm{d}, J=2.0 \mathrm{~Hz}), 123.9(\mathrm{~d}, J=5.3 \mathrm{~Hz}), 122.8,115.1(\mathrm{~d}, J=14.8$ $\mathrm{Hz}), 21.6 ;{ }^{19} \mathrm{~F}-164.5$.

\section{3-Fluoro-5-(4-methylphenyl)-2-phenyl-4-(phenylsulfanyl)furan (13)}

A $10 \mathrm{~mL}$ microwave reaction vial was charged with the iodofuran 9a $(0.095 \mathrm{~g}, 0.25 \mathrm{mmol})$, diphenyl disulfide $(0.055 \mathrm{~g}$, $0.25 \mathrm{mmol}), \mathrm{PdCl}_{2}(\mathrm{dppf})(0.019 \mathrm{mg}, 0.025 \mathrm{mmol})$, and zinc dust $(0.030 \mathrm{~g}, 0.50 \mathrm{mmol})$. The reaction vial was sealed, evacuated and backfilled with nitrogen (Schlenk line, three times). Under nitrogen protection, anhydrous degassed THF $(2.5 \mathrm{~mL})$ was injected into the vial. The reaction vial was submitted to microwave irradiation with stirring $\left(110{ }^{\circ} \mathrm{C}, 4 \mathrm{~h}\right)$. The reaction mixture was filtered through a Bücher funnel with the aid of ether $(60 \mathrm{~mL})$ and the filtrate was washed with brine $(10 \mathrm{~mL})$. The organic layer was dried over $\mathrm{MgSO}_{4}$, filtered and concentrated under vacuum. The residue was purified by silica gel column chromatography (hexanes) to give $\mathbf{1 3}$ as a white soft solid $(0.031 \mathrm{~g}, 0.086 \mathrm{mmol}, 34 \%)$. IR $\left(v, \mathrm{~cm}^{-1}, \mathrm{KBr}\right) 2924$, 1653, 1559. HRMS (DART-TOF) Calcd for $[\mathrm{M}+\mathrm{H}]^{+}$ $\mathrm{C}_{23} \mathrm{H}_{18} \mathrm{FOS}$ : 361.1062. Found: 361.1055. NMR $\left(\mathrm{CDCl}_{3}, \delta\right.$, ppm): ${ }^{1} \mathrm{H} 8.01(\mathrm{~d}, J=8.3 \mathrm{~Hz}, 2 \mathrm{H}), 7.82-7.75(\mathrm{~m}, 2 \mathrm{H}), 7.46(\mathrm{t}$, $J=7.8 \mathrm{~Hz}, 2 \mathrm{H}), 7.33-7.14$ (m, 8H), 2.39 (s, 3H); ${ }^{13} \mathrm{C} 152.6$ (d, $J=4.5 \mathrm{~Hz}), 150.4(\mathrm{~d}, J=255.5 \mathrm{~Hz}), 139.4,136.5,136.0,135.6$ $(\mathrm{d}, J=19.9 \mathrm{~Hz}), 129.6(2 \mathrm{C}), 129.4(2 \mathrm{C}), 129.0(2 \mathrm{C}), 127.7$, $127.2(\mathrm{~d}, J=1.5 \mathrm{~Hz}), 127.1(2 \mathrm{C}), 126.2,126.1(2 \mathrm{C}), 123.8$ (d, $J=5.1 \mathrm{~Hz}, 2 \mathrm{C}), 102.7(\mathrm{~d}, J=20.3 \mathrm{~Hz}), 21.6 ;{ }^{19} \mathrm{~F}-160.5$.

\section{Crystallography}

Crystals of $6 \mathbf{e}$ (transparent prism, colorless) were grown by evaporation of hexanes/ethyl acetate $(20: 1)$ solution. Crystals of $\mathbf{8 a}$ (transparent needle, colorless) were grown from the ether by slow evaporation. Crystals of $\mathbf{1 0}$ (transparent needle, colorless) were grown from the pentane by slow evaporation. CCDC 826570,826571 , and 827011 , respectively (see the supplementary crystallographic data for this papert).

\section{Acknowledgements}

Acknowledgment is made to the donors of the Petroleum Research Fund (ACS-PRF\#46094) administered by the American Chemical Society and to Oakland University and its Research Excellence Program in Biotechnology for the support of this research. The National Science Foundation (NSF) awards (CHE-0821487, CHE-1048719, and CHE-0722547) are also acknowledged. Y. L. is grateful for the Provost's Graduate Student Research Award. We also thank Dr Robert Syvret (Air Products and Chemicals), Dr Bruno François (Simafex, France), and Frontier Scientific, Logan, Utah, for a generous supply of Selectfluor, $N$-iodosuccinimide, and boronic acid/lithium triisopropoxyborate salt (LTBS), respectively.

\section{References}

1 E. P. Cormier, M. Das, and I. Ojima, Approved Active Pharmaceutical Ingredients Containing Fluorine, in Fluorine in Medicinal Chemistry and Chemical Biology,ed. I. Ojima, Wiley-Blackwell, Chichester, 2009, pp. 525-603.

2 J.-P. Bégué and D. Bonnet-Delpon, Bioorganic and Medicinal Chemistry of Fluorine, John Wiley \& Sons, New York, 2008, pp. 279-351.

3 Wikipedia, the free encyclopedia, List of bestselling drugs, http://en.wikipedia.org/wiki/List_of_bestselling_drugs (accessed August 30, 2011).

4 Review: O. Serdyuk, A. Butin and V. Abaev, J. Fluorine Chem., 2010, 131, 296-319.

5 A. S. Cantrell, P. Engelhardt, M. Högberg, R. S. Jaskunas, N. G. Johansson, C. L. Jordan, J. Kangasmetsä, M. D. Kinnick, P. Lind, J. M. Morin Jr., M. A. Muesing, R. Noreén, B. Öberg, P. Pranc, C. Sahlberg, R. J. Ternansky, R. T. Vasileff, L. Vrang, S. J. West and H. Zhang, J. Med. Chem., 1996, 39, 4261-4274.

6 See for example: (a) J. R. Thomas and P. J. Hergenrother, Chem. Rev., 2008, 108, 1171-1224; (b) N. Issaeva, P. Bozko, M. Enge, M. Protopopova, L. G. G. C. Verhoef, M. Masucci, A. Pramanik and G. Selivanova, Nat. Med., 2004, 10, 1321-1328; (c) X. Ming, W. Ju, H. Wu, R. R. Tidwell, J. E. Hall and D. R. Thakker, Drug Metab. Dispos., 2009, 37, 424-430; (d) M. M. Nyunt, C. W. Hendrix, R. P. Bakshi, N. Kumar and T. A. Shapiro, Am. J. Trop. Med. Hyg., 2009, 80, 528-535.

7 S. Arimitsu, J. M. Jacobsen and G. B. Hammond, J. Org. Chem., 2008, 73, 2886-2889.

8 See for example: (a) M. Hussain, R. A. Khera, N. T. Hung and P. Langer, Org. Biomol. Chem., 2011, 9, 370-373; (b) S. A. Schweizer and T. Bach, Synlett, 2010, 81-84.

9 A. S. Karpov, E. Merkul, T. Oeser and T. J. J. Müller, Eur. J. Org. Chem., 2006, 2991-3000.

10 A. Sniady, M. S. Morreale, K. A. Wheeler and R. Dembinski, Eur. J. Org. Chem., 2008, 3449-3452.

11 C.-H. Cho and R. C. Larock, ACS Comb. Sci., 2011, 13, 272-279.

12 R. Dembinski, Y. Li, D. Gundapuneni and A. Decker, Synthesis of $\beta$-Halofurans, in Halogenated Heterocycles: Synthesis and Use, ed. J. Iskra, Topics in Heterocyclic Chemistry Series, Springer, Heidelberg, 2011, vol. 27, ch. 3, pp. 63-98.

13 Representative reviews for synthesis of furans: $(a)$ H. N. C. Wong, X.L. Hou, K.-S. Yeung and H. Huang, Five-Membered Heterocycles: Furan. InModern Heterocyclic Chemistry, J. Alvarez-Builla, J. J. Vaquero and J. Barluenga, Eds., Wiley-VCH: Weinheim, 2011, Vol. 1, Ch. 6, 533592; (b) N. T. Patil and Y. Yamamoto, Arkivoc, 2007, 10, 121-141; (c) S. F. Kirsch, Org. Biomol. Chem., 2006, 4, 2076-2080; (d) R. C. D. Brown, Angew. Chem., Int. Ed., 2005, 44, 850-852.

14 (a) B. Godoi, R. F. Schumacher and G. Zeni, Chem.Rev., 2011, 111, 2937-2980; (b) For a general review on the cyclizations of alkynes see: K. Gilmore and I. V. Alabugin, Chem. Rev., 2011, 111, 65136556.

15 Recent representative advances: (a) S. Ali, H.-T. Zhu, X.-F. Xia, K.-G. Ji, Y-F. Yang, X-R. Song and Y.-M. Liang, Org. Lett., 2011, 13, 2598-2601; (b) H.-T. Zhu, K.-G. Ji, F. Yang, L.-J. Wang, S.-C. Zhao, S. Ali, X.-Y. Liu and Y.-M. Liang, Org. Lett., 2011, 13, 684-687; (c) A. Sperança, B. Godoi, M. D. Costa, P. H. Menezes and G. Zeni, Tetrahedron Lett., 2011, 52, 388-391; (d) R. Sanz, A. Martínez, P. García-García, M. A. Fernández-Rodríguez, M. A. Rashid and F. Rodríguez, Chem. Commun., 2010, 46, 7427-7429; (e) K.-G. Ji, H.-T. Zhu, F. Yang, A. Shaukat, X.-F. Xia, Y.-F. Yang, X.-Y. Liu and Y.-M. Liang, J. Org. Chem., 2010, 75, 5670-5678; $(f)$ B. Crone, S. F. Kirsch and K.D. Umland, Angew. Chem., Int. Ed., 2010, 49, 4661-4664; $(g)$ R. F. Schumacher, A. R. Rosário, A. C. G. Souza, P. H. Menezes and 
G. Zeni, Org. Lett., 2010, 12, 1952-1955; (h) N. Fei, Q. Hou, S. Wang, H. Wang and Z. J. Yao, Org. Biomol. Chem., 2010, 8, 4096-4103; (i) S. Mehta and R. C. Larock, J. Org. Chem., 2010, 75, 1652-1658; (j) C.-H. Cho, B. Neuenswander and R. C. Larock, J. Comb. Chem., 2010, 12, 278-285.

16 Formal electrophilic reactions of fluorine presumably involve alternative mechanisms: T. Umemoto, S. Fukami, G. Tomizawa, K. Harasawa, K. Kawada and K. Tomita, J. Am. Chem. Soc., 1990, 112, 8563-8575.

17 P. Li, Z. Chai, G. Zhao and S.-Z. Zhu, Synlett, 2008, 2547-2551.

18 For conversion of 2,5-substituted 3-fluorofurans into 2,3,5-substituted see: (a) P. Li, J.-W. Gu, Y. Ying, Y.-M. He, H.-F. Zhang, G. Zhao and S.Z. Zhu, Tetrahedron, 2010, 66, 8387-8391; (b) P. Li, Z. Chai, G. Zhao and S.-Z. Zhu, Tetrahedron, 2009, 65, 1673-1678.

19 3-Fluorofuran-containing fatty ester was obtained using a similar reaction catalyzed by $(\mathrm{PhCN})_{2} \mathrm{PdCl}_{2}$ in propylene oxide in $50 \%$ yield: M. S. F. Lie Ken Jie, M. M. L. Lau and C. N. W. Lam, Lipids, 2003, 38, $1293-1297$.

20 M. S. F. Lie Ken Jie, M. M. L. Lau, C. N. W. Lam, M. S. Alam, J. O. Metzger and U. Biermann, Chem. Phys. Lipids, 2003, 125, 93-101.

21 H. L. Sham and D. A. Batebenner, J. Chem. Soc., Chem. Commun., 1991, 1134-1135

22 B. Xu and G. B. Hammond, J. Org. Chem., 2006, 71, 3518-3521.

23 Y. Li, K. A. Wheeler and R. Dembinski, Adv. Synth. Catal., 2010, 352, 2761-2766.

24 (a) A. Sniady, A. Durham, M. S. Morreale, A. Marcinek, S. Szafert, T. Lis, K. R. Brzezinska, T. Iwasaki, T. Ohshima, K. Mashima and R. Dembinski, J. Org. Chem., 2008, 73, 5881-5889; (b) A. Sniady, A. Durham, M. S. Morreale, K. A. Wheeler and R. Dembinski, Org. Lett., 2007, 9, 1175-1178; (c) P. Wyrębek, A. Sniady, N. Bewick, Y. Li, A. Mikus, K. A. Wheeler and R. Dembinski, Tetrahedron, 2009, 65, $1268-1275$.

25 Y. Li, K. A. Wheeler and R. Dembinski, Eur. J. Org. Chem., 2011, 27672771.

26 (a) A. Sniady, K. A. Wheeler and R. Dembinski, Org. Lett., 2005, 7 , 1769-1772; (b) M. S. Rao, N. Esho, C. Sergeant and R. Dembinski, J. Org. Chem., 2003, 68, 6788-6790.

27 Effort to facilitate electrophilic fluorocyclization of butynone 3a with Selectfluor was unsuccessful.

28 F. A. Davis and P. V. N. Kasu, Org. Prep. Proced. Int., 1999, 31, $125-$ 143.

29 G. Verniest, E. Van Hende, R. Surmont and N. De Kimpe, Org. Lett., $2006,8,4767-4770$.

30 For the synthesis of $\alpha$-fluoro ketones from alkynes see: T. de Haro and C. Nevado, Adv. Synth. Catal., 2010, 352, 2767-2772.

31 Matching observations has been reported for fluorination of enamines: W. Peng and J. M. Shreeve, J. Org. Chem., 2005, 70, 5760-5763.

32 D. Enders and M. R. M. Hüttl, Synlett, 2005, 991-993.

33 G. S. Lal, G. P. Pez and R. G. Syvret, Chem. Rev., 1996, 96, 1737-1756.

34 (a) S. Arimitsu and G. B. Hammond, Synthesis of gem-Difluorinated Heterocycles Using a Difluoropropargyl Molecular Scaffold, in Fluorinated Heterocycles, ed. A. A. Gakh and K. L. Kirk, ACS Symposium Series 1003, American Chemical Society, Washington, DC, 2009; pp. 135-162; (b) S. Arimitsu and G. B. Hammond, Chim. Oggi, 2010, 28, 20-22; (c) S. Arimitsu, B. Fernandez, C. del Pozo, S. Fustero and G. B. Hammond, J. Org. Chem., 2008, 73, 2656-2661.

35 See for example: J.-C. Kizirian, N. Aiguabella, A. Pesquer, S. Fustero, P. Bello, X. Verdaguer and A. Riera, Org. Lett., 2010, 12, 5620-5623.

36 For examples see: (a) C. Dai, L. Wang, J. Sheng, H. Peng, A. B. Draganov, Z. Huang and B. Wang, Chem. Commun., 2011, 47, 3598-3600; (b) E. M. Sletten, H. Nakamura, J. C. Jewett and C. R. Bertozzi, J. Am. Chem. Soc., 2010, 132, 11799-11805; (c) S. T. Laughlin, J. M. Baskin, S. L. Amacher and C. R. Bertozzi, Science, 2008, 320, 664-5667.

37 S. Arimitsu, B. Fernández, C. del Pozo, S. Fustero and G. B. Hammond, J. Org. Chem., 2008, 73, 2656-2661.

38 (a) A. Sniady, M. S. Morreale and R. Dembinski, Org. Synth., 2007, 84, 199-208; Org. Synth., 2009, Coll. Vol. 11, 794-801; (b) See also ref. $24 a$, and references therein.

39 A. S. Dudnik, Y. Xia, Y. Li and V. Gevorgyan, J. Am. Chem. Soc., 2010, 132, 7645-7655.

40 (a) V. Gouverneur and B. Greedy, Chem.-Eur. J., 2002, 8, 766-771 and references therein (b) E. Differding and H. Ofner, Synlett, 1991, 187189; (c) G. S. Lal, J. Org. Chem., 1993, 58, 2791-2796; (d) Y. Guo, G.-H. Tao, A. Blumenfeld and J. M. Shreeve, Organometallics, 2010, 29, $1818-1823$
41 A. Denichoux, F. Ferreira and F. Chemla, Org. Lett., 2004, 6, 3509 3512.

42 A. Padwa, D. J. Austin, Y. Gareau, J. M. Kassir and S. L Xu, J. Am. Chem. Soc., 1993, 115, 2637-2647.

43 (a) A. V. Anisimov, G. N. Murina, L. V. Mozhaeva, N. B. Kazennova and E. A. Viktorova, Chem. Heterocycl. Compd., 1984, 20, 599-601; Khim. Geterotsikl. Soed., 1984, 744-746; (b) K. Atsumi and I. Kuwajima, J. Am. Chem. Soc., 1979, 101, 2208-2211.

44 (a) I. Fleming and I. Paterson, Synthesis, 1979, 736-738; (b) H. O. House, L. J. Czuba, M. Gall and H. D. Olmstead, J. Org. Chem., 1969, 34, 2324-2336.

45 Phenylhexa-4,5-dien-3-one. Yellow oil. IR $\left(v, \mathrm{~cm}^{-1}\right.$, film) 2929, 1937, $1910,1715,1684,1456,699$. NMR $\left(\mathrm{CDCl}_{3}, \delta, \mathrm{ppm}\right):{ }^{1} \mathrm{H} 7.40-7.29(\mathrm{~m}$, $5 \mathrm{H}), 6.64(\mathrm{~d}, J=6.4 \mathrm{~Hz}, 1 \mathrm{H}), 6.16(\mathrm{~d}, J=6.4 \mathrm{~Hz}, 1 \mathrm{H}), 2.75-2.58(\mathrm{~m}$, $2 \mathrm{H}), 1.09(\mathrm{t}, J=7.4 \mathrm{~Hz}, 3 \mathrm{H}) ;{ }^{13} \mathrm{C} 215.3,201.1,131.4,129.3,128.4$, $127.5,100.4,98.8,33.1,8.6$.

46 The ratio was calculated based upon ${ }^{1} \mathrm{H}$ NMR integration of the vinyl protons.

47 C. H. Heathcock, C. T. Buse, W. A. Kleschick, M. C. Pirrung, J. E. Sohn and J. Lampe, J. Org. Chem., 1980, 45, 1066-1081. When the phenyl group is attached to the carbonyl function in regular ketones, the use of LDA usually promotes a dominance of $Z$ versus $E$ isomer.

48 D. A. Evans, K. M. Hurst and J. M. Takacs, J. Am. Chem. Soc., 1978, 100, 3467-3477.

49 H. J. Reich, R. C. Holtan and C. Bolm, J. Am. Chem. Soc., 1990, 112, 5609-5617.

50 For assignments with the use of a NOE experiment, see ref. 41

51 Y. Lu, F. Song, X. Jia and Y. Liu, Prog. Chem., 2010, 22, 58-70 (in Chinese).

52 (a) A. S. K. Hashmi, T. D. Ramamurthi and F. Rominger, Adv. Synth. Catal., 2010, 352, 971-975; (b) L.-P. Liu and G. B. Hammond, Chem.-Asian J., 2009, 4, 1230-1236; (c) A. S. K. Hashmi, A. Schuster and F. Rominger, Angew. Chem., Int. Ed., 2009, 48, 8247-8249; (d) D. Weber, M. A. Tarselli and M. R. Gagné, Angew. Chem., Int. Ed., 2009, 48, 5733-5736; (e) L.-P. Liu, B. Xu, M. S. Mashuta and G. B. Hammond, J. Am. Chem. Soc., 2008, 130, 17642-17643.

53 Representative recent reviews: (a) H. Huang, Y. Zhou and H. Liu, Beilstein J. Org. Chem., 2011, 7, 897-936; (b) M. Rudolph and A. S. K. Hashmi, Chem. Commun., 2011, 47, 6536-6544; (c) Y. Yamamoto, I. D. Gridnev, N. T. Patil and T. Jin, Chem. Commun., 2009, 5075-5087; . For the gold-catalysed cycloisomerisation of propargyl ketones see: $(d)$ A. S. K. Hashmi, L. Schwarz, J.-H. Choi and T. M. Frost, Angew. Chem., Int. Ed., 2000, 39, 2285-2288; . See also: (e) S. Hummel and S. F. Kirsch, Beilstein J. Org. Chem., 2011, 7, 847859 .

54 (a) Y. Yamamoto, J. Org. Chem., 2007, 72, 7817-7831; (b) Y. Xia, A. S. Dudnik, V. Gevorgyan and Y. Li, J. Am. Chem. Soc., 2008, 130, 6940-6941; . For a recent theoretical insight into the activity of gold catalysts see: (c) A. S. K. Hashmi, M. Pernpointner and M. M. Hansmann, Faraday Discuss., 2011, 152, 179-184.

55 For another combination of a $\mathrm{Au} / \mathrm{Zn}$ catalyst see: A. S. Demir, M. Emrullahoğlu and K. Buran, Chem. Commun., 2010, 46, 8032-8034.

56 In addition, the participation of triflic acid (HOTf, which would be delivered from a metal triflate catalyst) in the catalytic cycle could be considered. However, reaction with sole triflic acid $(10 \mathrm{~mol} \%)$ led to the decomposition of the fluoroketone and formation of the multiple products including regular furan $7 \mathbf{a}$.

57 To diminish formation of the enolate anion that increases partition of the product in the water phase, $5 \% \mathrm{NaHCO}_{3}$ was used instead of saturated $\mathrm{Na}_{2} \mathrm{CO}_{3}$ in an extraction step.

58 Selectfluor has been reported as the mediator for many types of reactions, for example see: (a) S. Stavber and M. Zupan, Acta Chim. Slov., 2005, 52, 13-26; (b) S. Stavber, Molecules, 2011, 16, 6432-6464. Also, the ether $\mathbf{6 h}$ possesses a skeleton that would be potentially vulnerable to the aromatic Claisen rearrangement.

59 W. Xu and Q.-Y. Chen, Org. Biomol. Chem., 2003, 1, 1151-1156.

60 For selected NBS/gold catalytic systems see: (a) F. Mo, J. M. Yan, D. Qiu, F. Li, Y. Zhang and J. Wang, Angew. Chem., Int. Ed., 2010, 49, 2028-2032; (b) A. Leyva-Pérez, P. Rubio-Marqués, S. S. Al-Deyab, S. I. Al-Resayes and A. Corma, ACS Catal., 2011, 1, 601-606.

61 (a) K. L. Billingsley and S. L. Buchwald, Angew. Chem., Int. Ed., 2008, 47, 4695-4698; (b) L. Ackermann and H. K. Potukuchi, Synlett, 2009, 2852-2856; See also: (c) A. N. Cammidge, V. H. M. Goddard, H. Gopee, N. L. Harrison, D. L. Hughes, C. J. Schubert, B. M. Sutton, G. L. Watts and A. J. Whitehead, Org. Lett., 2006, 8, 4071-4074. 
62 J. Z. Deng, D. V. Paone, A. T. Ginnetti, H. Kurihara, S. D. Dreher, S. A. Weissman, S. R. Stauffer and C. S. Burgey, Org. Lett., 2009, 11, 345-347.

$63 \mathrm{http} / / /$ www.frontiersci.com/index.php?module/Pages\&func/display\&pageid/18\&cat/Chemistry.
64 S. Fukuzawa, D. Tanihara and S. Kikuchi, Synlett, 2006, 2145-2147.

65 Six peaks exhibiting a splitting pattern of pseudo triplet of doublet were observed. The estimated values were determined as $v_{\mathrm{A}}=1 / 2\left(\delta_{2}+\delta_{5}\right), J_{\mathrm{AX}}$ $\approx \delta_{2}-\delta_{5}$.

66 One signal is obscured. 